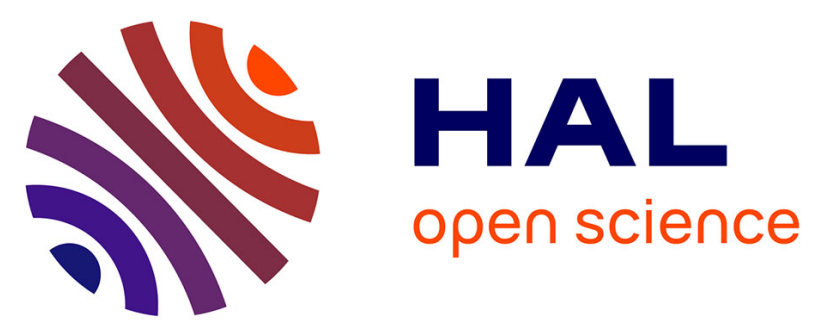

\title{
Volcanic record of continental thinning in Baffin Bay margins: Insights from Svartenhuk Halvø Peninsula basalts, West Greenland
}

Arnaud Agranier, René C. Maury, Laurent Geoffroy, François Chauvet, Bernard Le Gall, Adriano R. Viana

\section{To cite this version:}

Arnaud Agranier, René C. Maury, Laurent Geoffroy, François Chauvet, Bernard Le Gall, et al.. Volcanic record of continental thinning in Baffin Bay margins: Insights from Svartenhuk Halvø Peninsula basalts, West Greenland. Lithos, 2019, 334, pp.117 - 140. 10.1016/j.lithos.2019.03.017 . hal03485028

\section{HAL Id: hal-03485028 \\ https://hal.science/hal-03485028}

Submitted on 20 Dec 2021

HAL is a multi-disciplinary open access archive for the deposit and dissemination of scientific research documents, whether they are published or not. The documents may come from teaching and research institutions in France or abroad, or from public or private research centers.
L'archive ouverte pluridisciplinaire HAL, est destinée au dépôt et à la diffusion de documents scientifiques de niveau recherche, publiés ou non, émanant des établissements d'enseignement et de recherche français ou étrangers, des laboratoires publics ou privés.

\section{(ㅇ)(1) $\$$}

Distributed under a Creative Commons Attribution - NonCommerciall 4.0 International 


\section{Volcanic record of continental thinning in Baffin Bay \\ 2 margins: insights from Svartenhuk Halvø Peninsula basalts, \\ 3 West Greenland}

5 Arnaud Agranier ${ }^{\mathrm{a}^{*}}$, René C. Maury ${ }^{\mathrm{a}}$, Laurent Geoffroy ${ }^{\mathrm{a}}$, François Chauvet ${ }^{\mathrm{ab}}$, Bernard Le

6 Gall $^{\mathrm{a}}$, Adriano R. Viana ${ }^{\mathrm{c}}$

$8{ }^{a}$ Univ Brest, CNRS, IUEM, UMR 6538 Laboratoire Géosciences Océan, Rue Dumont

9 d'Urville, 29280 Plouzané, France

$10{ }^{b}$ UMR $6538 /$ UBO / SEDISOR

$11{ }^{\mathrm{c}}$ Petrobras, Petróleo Brasileiro S.A., Rio de Janeiro, 1301E Brazil; E\&P/UN-

12 RIO/ATEX/ABIG-PL

13

14 * Corresponding author: Tel.: +33 2984987 07, fax: +33 2984987 60. E-mail

15 address: arnaud.agranier@univ-brest.fr

18 Keywords

19 Plume-related basalts

20 Enriched mantle sources

21 Partial melting

22 West Greenland Volcanic Province

23 North Atlantic Igneous Province

24 Volcanic passive margins

25

8088 words, 52773 characters

\section{Abstract}

We report major, trace elements and $\mathrm{Pb}, \mathrm{Hf}, \mathrm{Nd}$ and $\mathrm{Sr}$ isotopes in 61-54 Ma old basalts

31 from Svartenhuk Halvø Peninsula (Greenland). This area corresponds to the

32 northernmost exposure of the West Greenland volcanic province, of which the

33 emplacement marks the continental thinning and breakup process leading to the opening 
of Baffin Bay during the Eocene. Its wedge structure displays typical characteristics of inner seaward-dipping-reflectors (SDR) with an exposed volcanic sequence thicker than $7 \mathrm{~km}$. Our results cover the entire volcanic sequence starting with an earliest V1 unit reflecting rather low degree partial melts (transitional basalts), which are geochemically imprinted by continental crust contamination. This unit is followed by much thicker and mainly tholeiitic V2 and V3 basaltic lava piles, and ends with a rather thin V4 unit, consisting of alkali basalts and associated trachytes. Pressures and temperatures of melt extraction were estimated based on major element concentrations and rare earth elements patterns. Our results suggest that melts were extracted from the garnet-spinel transition zone at greater depths for the initial V1 and the final V4 lavas (alkali to transitional basaltic compositions) than for the main V2 and V3 mostly tholeiitic lava piles (at $2 \pm 0.5 \mathrm{GPa}$ and $1350 \pm 100^{\circ} \mathrm{C}$ ). Isotope signatures suggest that mantle sources of the melts were controlled by the mixing of ambient upper mantle and Icelandic plume-type materials. The proportion of ambient upper mantle involved in the lava source appears to increase together with melting rates and the upward propagation of melting zone during V3 emplacement, suggesting that melting in this area progessed as follows: 1. Initiation of partial melting (low degrees) of deep-seated Icelandic plumetype material (V1 and V2); 2. Upward propagation of the melting area within the shallower mixed upper mantle (V3); 3. Progressive decrease of "ambient upper mantle" involvement, deepening of magma extraction and decrease of partial melting associated with the emplacement of V4 lavas. We show that these changes are consistent with the tectonic stages of continental thinning that preceded the Eocene breakup in Baffin Bay.

\section{Introduction}

Volcanic passive margins (VPM) characterize continental breakup associated with the emplacement of large igneous provinces (White and McKenzie, 1989; Coffin and Eldholm, 1994). In detail, initial mantle melting is thought to start prior to significant

61 lithosphere extension (Courtillot et al., 1999), leading to the eruption of voluminous flood basalts. Then, focusing of mantle melting combined with lithosphere extension and consecutive syn-magmatic break-up leads to the formation of volcanic passive margins (Geoffroy et al., 2015). The corresponding volcanic sequences, although emplaced subaerially, are usually found as immerged seaward-dipping reflectors (SDR) sequences beneath post-rift sediments, a common occurrence throughout the North

67 Atlantic Igneous Province (NAIP; Saunders et al., 1997). Such sequences, linked to the 
opening of the Baffin Bay oceanic basin, are exceptionally well-exposed along the West Greenland coast, where they are of Paleocene-Eocene age and up to 5-7 km thick (Larsen and Pulvertaft, 2000; Larsen and Pedersen, 2009; Larsen et al., 2015; Chauvet et al., accepted). Petrologic and geochemical studies of these volcanic successions as well as those of similar sequences exposed in the East Greenland margin raise several important (and still debated) petrogenetic and tectono-magmatic questions, e.g. (1) do the considerable volumes of erupted picrites indicate abnormally high temperatures of partial melting of plume-related materials (Francis, 1985; Larsen and Pedersen, 2000, 2009; Hole and Millett, 2016); (2) does the heterogeneity of the mantle sources of Paleocene-Eocene mafic magmas foreshadow that of the present-day Icelandic hotspot (Holm et al., 1993; Peate and Stecher, 2003; Barker et al., 2006); and finally (3) does the temporal evolution of melting rates and depths record the successive stages of continental extension and rupture in the East (Larsen and Saunders, 1998; Abdelmalak et al., 2012, 2018) and West Greenland (Tegner et al., 1998; Barker et al., 2006) margins as well as in other parts of the NAIP (Kerr, 1994; Geoffroy, 2005; Meyer et al., 2007; Saunders et al., 2007)?

Svartenhuk Halvø Peninsula represents the northernmost exposure of the West Greenland Volcanic Province. The Svartenhuk wedge typically displays the structural and stratigraphic characteristics of inner-SDR wedges observed on deep seismic reflection profiles from VPM worldwide (e.g. Planke et al. 2000; Stica et al., 2014; Geoffroy et al., 2015). The thickness of the exposed volcanic sequence may reach up to $7 \mathrm{~km}$ and at least one third of it is made of picrites (Larsen and Pulvertaft, 2000). The aims of the present study are (1) to analyze magmatic processes such as mantle source heterogeneity, depths and rates of partial melting, and crustal contamination that occurred during the c. 10 m.y. of its emplacement (i.e. from 62.5-61 Ma to 54-53 Ma; Larsen et al., 2015; Chauvet et al., accepted), and (2) to discuss their temporal evolution during the successive stages of the continental stretching and thinning margin system related to the opening of the Baffin Bay oceanic basin.

\section{Geological setting}

2.1. The Labrador-Baffin oceanic domain and West Greenland Volcanic Province 

including the NE-Atlantic area between Eurasia and Greenland (Fig. 1). A continental and diachronous rift system developed between Greenland and Canada during the

104 Cretaceous. This a-magmatic extension led to continental breakup with mantle 105 exhumation in the southern Labrador Sea. A now extinct oceanic spreading axis in the 106 Labrador Sea led to the drifting apart of Greenland from North America since the Late 107 Cretaceous (Roest and Srivastava, 1989) or Paleocene (Chalmers and Laursen, 1995) and ceased to operate during the Oligocene ( magnetochron C13, Roest and Srivastava, 1989). The SW-NE-trending left-lateral Ungava transform-fault system (UFS) connected the Labrador Sea to Baffin Bay farther North (Fig. 1).

111 In the northern Labrador Sea, the oldest undisputed oceanic magnetic anomaly has 112 a mid-Paleocene age (Chalmers and Laursen, 1995), i.e. C27n (62.2 - 62.5 Ma, 113 according to Ogg, 2012). During the Paleocene, the spreading directions were oriented $114 \sim$ N060E, i.e. sub-orthogonal to earlier rifted structures on the conjugate margins. Both 115 the oceanic fracture zones and magnetic anomalies in the Labrador Sea indicate that a 116 major shift in kinematics occurred during the Early Eocene, between C25 and C24, 117 when spreading directions rotated from N060E to N010E (Roest and Strivastava, 1989; 118 Geoffroy et al., 2001; Fig. 1).

119 In Baffin Bay, the age of the earliest accretion is still debated since no obvious 120 linear magnetic anomalies can be identified on its floor, although there is a consensus 121 for the cessation of spreading during the Oligocene (Roest and Strivastava, 1989; Oakey 122 and Chalmers, 2012). Two major N-S-trending fracture zones in the central part of the 123 Baffin Bay (Fig. 1) suggest that oceanic spreading may have been coeval with the $\sim \mathrm{N}-\mathrm{S}$ 124 reorientation of the kinematic trend in the Labrador Sea during Eocene (Chalmers and 125 Pulvertaft, 2001; Geoffroy et al., 2001; Suckro et al., 2012; Funck et al., 2012). Other 126 authors (Oakey and Chalmers, 2012; Suckro et al., 2012; Hosseinpour et al., 2013) 127 consider that earlier oceanic-type crust of mid-Paleocene age could exist within Baffin 128 Bay. However, none of these studies took into account the age of continental stretching and thinning recorded along the Baffin Bay continental passive margins.

130 The conjugate passive margins in Baffin Bay (Fig. 1) are clearly of volcanic type 131 in the South of the basin (Geoffroy et al., 2001; Skaarup et al., 2006; Block et al., 2012). 132 The inner part of the SE-Baffin volcanic passive margin (VPM) is largely exposed from 133 latitudes $69^{\circ} \mathrm{N}$ to $72^{\circ} \mathrm{N}$ in the Disko-Svartenhuk area (Fig. 1). An inner-SDR (Planke et 134 al., 2000) developed orthogonally to the regional stretching direction during the 
135 Paleogene (Geoffroy et al., 2001; Abdelmalak et al., 2012) and is fully exposed at

136 Svartenhuk where its total thickness reaches up to $7 \mathrm{~km}$. Recently published Ar-Ar ages

137 (Larsen et al., 2015; Chauvet et al., accepted) that range from 62.5-61 Ma to 54-53 Ma

138 for Svartenhuk basalts provide new constraints for the tectono-magmatic evolution of

139 the Baffin Bay margin system.

\subsection{The Svartenhuk Halv $\varnothing$ Peninsula}

142 The tectonics of the Svartenhuk SDR has already been investigated (Larsen and 143 Pulvertaft, 2000; Geoffroy et al., 2001; Abdelmalak et al., 2012). Until recently, the age 144 of the regional strain remained a matter of debate due to the lack of age determinations 145 on lavas in this area (see discussion in Larsen and Pulvertaft, 2000). However, new sets 146 of ${ }^{40} \mathrm{Ar} /{ }^{39} \mathrm{Ar}$ ages recently published by Larsen et al. (2015) and Chauvet et al.

147 (accepted) provide new constraints on the timing of melting processes at the scale of the 148 NAIP. In Svartenhuk Peninsula, the thickness of the exposed volcanic sequence may 149 reach up to $7 \mathrm{~km}$ (Larsen and Pulvertaft, 2000). Its dense fault network results from a seaward-migrating strain (Geoffroy et al., 2001). The Arfertuarssuk Fault represents the

151 exposed master fault bounding and controlling the development of the Svartenhuk 152 wedge (Fig. 2).

153 In the present study and in the companion paper by Chauvet et al. (accepted)

154 dealing with the same sample set, the volcanic formations making up the SDR wedge in 155 Svartenhuk Halvø have been subdivided into four successive sequences (labeled V1 to 156 V4 upwards; Fig. 2) (Fig. 2). The boundaries between these sequences are consistent 157 with the geological and petrographic distinctions of Larsen (1983) and Larsen and 158 Grocott (1992).

159 Coeval volcanics crop out on Disko Island, Nuussuaq Peninsula and Ubekendt 160 Ejland Island, where they form a plurikilometric pile of ultramafic to mafic Paleogene 161 lavas crosscut by sheeted intrusions (e.g. Pedersen et al., 2002). The stratigraphy and 162 age of the W-Greenland basalts were defined in these areas as follows (Storey et al., 1631998 and references therein). The Vaigat Fm. consists of a lower sequence dominated 164 by hyaloclastites and pillow lavas overlain by picrites and Mg-rich subaerial basalts. 165 The earliest subaqueous volcanics unconformably overlie the remnants of an Early 166 Cretaceous to Paleogene paleobasin (Fig. 2). The overlying Maligât Fm. is dominated 167 by feldspar-phyric and aphyric basalts associated with a sharp change in lava chemistry 168 (Larsen and Pedersen, 2009). Larsen and Pulvertaft (2000) suggested that the lava 
stratigraphy established in the Disko-Nuussuaq area could be applied to the Svartenhuk area. As such, the V1 and V2 formations correlate with the southern Vaigat Formation,

171 while the "Svartenhuk Fm." (V3 in Fig. 2) would be equivalent to the Maligât Fm. (Fig.

172 3). In Svartenhuk Halvø, a 1-2 km thick succession of transitional to alkaline basalts

173 (V4 unit) lies above the V3 unit. A stratiform sill-like trachytic body marks the

174 boundary between the V3 and V4 units. Larsen and Grocott (1992) considered these

175 basalts and trachyte as the uppermost part of the Svartenhuk Fm. According to Larsen et

176 al. (2015), this succession belongs to a newly introduced Naqerloq Fm. (Fig. 2),

177 dominated by transitional light rare Earth element (LREE) enriched basalts.

178 From observations on the Disko and Nuussuaq areas, two main volcanic pulses

179 have been identified and further correlated by radiometric dating and paleomagnetic

180 data (Storey et al., 1998; Riisager and Abrahamsen, 1999; Riisager et al., 2003). The

181 earliest pulse was mid-Paleocene in age and spans chrons 27n and 26r (62.5-59.2 Ma

182 after Ogg, 2012). The second pulse occurred during the early Eocene at C24r (54-

$18357 \mathrm{Ma})$, i.e., after a hiatus of 2 m.y. or more. An Early Eocene age was obtained from

184 the basaltic succession of the Kanísut Mb. (Storey et al., 1998), that crops out

185 exclusively West of the Itilli fault, and which is seaward tilted at about $15^{\circ}$ (Fig. 2,

186 Riisager et al., 2003). These basalts lie unconformably above the Vaigat-Maligat

187 basalts, which are in turn deeply down-faulted westward (Larsen et al., 2015). It is

188 noteworthy that early Eocene ages were also obtained for dykes crosscutting the

189 Paleocene-related series in Disko and Nuussuaq (Storey et al., 1998) and also in the

190 Svartenhuk Peninsula (Geoffroy et al., 2001). Larsen et al. (2015) proposed that the

191 Paleocene magmatic pulse in West Greenland spans not only C27n-C26r but also up to

192 chron $\mathrm{C} 25 \mathrm{r}(59-57.7 \mathrm{Ma})$, based on four ${ }^{40} \mathrm{Ar} /{ }^{39} \mathrm{Ar}$ ages ranging from $60.3 \pm 1.4 \mathrm{Ma}$ to

$19358.0 \pm 0.6 \mathrm{Ma}$ on Svartenhuk Fm. basalts from the northern part of the Svartenhuk

194 peninsula. This implies that the Svartenhuk Fm. was mostly contemporaneous with the

195 Maligât Fm. but that its upper part was younger. These authors also outlined that the

196 transitional to alkaline basaltic successions exposed along the Arfertuarssuk Fault in

197 Svartenhuk Halvø (V4 unit) and on the western parts of the Ubekendt Ejland, Nuussuaq

198 peninsula and Hareøen are all early Eocene in age (Naqerloq and Erqa Fms). Chauvet et

199 al. (accepted) point out that both in W-Nuussuaq and Svartenhuk the Eocene lavas are

200 part of the syn-extension inner SDR, i.e. that continental crust thinning and stretching

201 still occurred during the Eocene (fig. 2). 
We investigated and sampled 45 sites mostly located along the coastal crosssection of the Svartenhuk volcanic margin (Fig. 1). Hyaloclastic sub-aquatic breccias and associated pillowed lavas formed in a lacustrine environment (Escher and Pulvertaft, 1995) are characteristic of the lower member of the Vaigat Fm (V1 unit, sampling sites 40 and 38). They are up to $200 \mathrm{~m}$ thick and dip $20-30^{\circ}$ westwards. These dips are mostly of tectonic origin but may also be due to dipping prograding foresets (Jerram, 2002), which have been identified for instance in the Naajaat syn-volcanic

211 lake, Nuussuaq Basin (Pedersen et al., 1998). Svartenhuk hyaloclastic breccias consist 212 of basaltic glassy clasts and pillow fragments, usually of centimeter- to decimeter-size, 213 set in a matrix of yellowish glass particles altered to clays and palagonite. Locally, 214 preserved pillow piles form cliffs up to 10-15 $\mathrm{m}$ high which delineate small high points 215 on the shoreline. Individual basaltic pillows, $10 \mathrm{~cm}$ to $1 \mathrm{~m}$ large, display typical glassy 216 margins and radial fractures together with flow features consistent with their emplacement over moderate slopes. Attempts to recover geochemically fresh glassy basaltic rims were unsuccessful, but the cores of large pillows proved to be rather well preserved from post-magmatic alteration.

Lava flows from V2, V3 and V4 units were exclusively emplaced in subaerial environments as suggested by lack of pillow lavas and hyaloclastites and common occurrence of pahoehoe surface features. Their most common facies, especially in V3 and V4 units, is that of individual tabular flows, 1 to $10 \mathrm{~m}$ thick. They generally show a basal scoriaceous autoclastic breccia, which overlies a reddish thermal metamorphic sole. These breccias are, in turn, overlain by a massive basaltic part often displaying rough columnar-jointing patterns, and less frequently sheet flow patterns. The rather common occurrence, in these massive levels, of subvertical vesicle pipes, sometimes feeding horizontal vesicle sheets (Caroff et al., 2000), suggests that the Svartenhuk

229 Peninsula basaltic magmas were water-rich at the time of their emplacement. Tuff 230 horizons usually less than $50 \mathrm{~cm}$ thick are occasionally interbedded between these 231 tabular flows, and probably correspond to subaerial ash and/or lapilli fall deposits. 232 Intercalated reworked (volcanic-sedimentary) deposits are much less common than in 233 Disko and Nuussuaq (Larsen and Pedersen, 2000). They correspond to basaltic pebble 234 conglomerates of probable laharic origin, filling local topographic channels. Their 235 maximal thickness is less than $10 \mathrm{~m}$ (sites 44 and 45), and they are sometimes overlain 236 by layered clay horizons less than $1 \mathrm{~m}$ thick. 
Vaigat Fm picrites (V2 unit) and less commonly Vaigat and Svartenhuk Fms tholeiitic basalts (V2 and V3) display a more specific emplacement facies, i.e. a compound-braided flow facies (Jerram, 2002). The corresponding lava piles, up to $30 \mathrm{~m}$ thick (site 39), have a typical grayish color also characteristic of Disko and Nuussuaq 241 picrites, (Larsen and Pedersen (2009), and are usually deeply altered and converted into 242 assemblages of post-magmatic minerals (mostly zeolites and carbonates). They consist 243 of thin (usually less than $50 \mathrm{~cm}$ thick) anastomosed individual layers emplaced as sheets 244 and lobes of pahoehoe lava breakouts. These individual lobes are elongated (up to several meters) and usually hollow; all the transitions are observed between meter-size lobes and typical lava tubes. Well preserved small pahoehoe ropy lava "tongues" often occur within the central cavity of these lobes or tubes, and provide good markers of flow emplacement patterns. In V2 and V3 units they point usually upwards due to the tectonic tilting of these sequences. Massive (and geochemically better preserved) porphyritic layers $50 \mathrm{~cm}$ to $2-3 \mathrm{~m}$ thick are common within the lobe/tube piles. They display intrusive relationships with respect to them (locally chilled margins) and are thought to result from inflation processes within the pahoehoe compound flow sequences (Jerram, 2002; Self et al., 1997). In the studied picritic lava sequences, both pahoehoe lobes/tubes and intrusive (inflation-related) sheets commonly contain large vesicles and vesicle pipes typical of water-rich magma emplacement features (Caroff et al., 2000). These facies are often ascribed to relatively low volume, low viscosity eruptions occurring during early stages of emplacement of continental flood basalts (Jerram, 2002).

Most dykes range in width from $10-20 \mathrm{~cm}$ to $2-3 \mathrm{~m}$, and display characteristic jointing patterns perpendicular to their chilled margins (which are glassy to microlitic) and have coarser-grained, often porphyritic, vesicle-rich central parts. These dykes tend to form swarms associated with fracture zones, and composite (multiple) dykes are common. Sills are usually easily distinguished from lava flows by their larger and more

264 regular columnar jointing patterns. The thickest ones (>10 m) display evidence for gravitational settling of olivine phenocrysts, which accumulate above their lower chilled margin.

\section{Sampling and analytical methods}

\subsection{Sampling strategy}


Sampling was conducted in 45 sites mostly located along the coastal cross-section of the volcanic margin (Table 1 and Fig. 2), from the basal lacustrine hyaloclastites and pillow basalts of the Vaigat Fm (labelled V1 in the geochemical discussion below; sites 40 and 38) towards successively: the subaerial picritic and basaltic flows of the main Vaigat Fm (labelled V2; sites 37, 39, 41, 42, 20, 43, 45, 44, 5, 3, 6, 7, 1, 27, 25, 28); then those of the overlying Svartenhuk Fm (labelled V3; sites 4, 2, 36, 35, 8, 31, 32, 11 , $10,34,12,9,33$ ); and finally the trachytic intrusion (site 29) and the subaerial alkali basaltic lava flows from the top of the Svartenhuk Fm, recently attributed to the Naqerloq Fm by Larsen et al. (2015) (site 30, labelled V4 below). Additional samplings were done for V2 (sites 19, 22, 23, 16, 14, 15, 13), V3 (site 26) and V4 (site 21). Major, trace element and isotopic measurements were only carried out on samples from lava flows, dykes and sills which were relatively fresh based on their macroscopic and microscopic features, and from which zeolite- and carbonate-bearing vesicles were removed by handpicking. The corresponding analytical database includes 5 samples from V1, 53 from V2, 28 from V3 and 5 from V4 lava flows, together with 47 intrusive (sills, dikes) samples (Tables 1, 2, 3 and 4). Most of the pillow fragments collected from V1 are altered (Loss on Ignition higher than $1.9 \mathrm{wt} \%$ ), and a number of compoundbraided basaltic flows (pahoehoe lobes and lava tube piles, see below), especially from V2, are too rich in secondary minerals (zeolites and carbonates) to have retained their primary magmatic features. Such samples were primarily collected to investigate these post-magmatic mineral associations found as vesicle fillings and vein/fracture deposits (57 samples from V2 and V3).

\subsection{Analytical methods}

All samples were subsequently crushed in stainless steal and agate mortars. Major element concentrations were obtained using an ICP-AES Jobin Yvon Ultima 2 at the University of Brest, after a $\mathrm{HF}-\mathrm{HNO}_{3}$ digestion, boric acid neutralization and dilution in nitric acid, as described in Cotten et al. (1995). Trace element concentrations were measured with a Thermo® Element2 HR-ICP-MS in Brest. $15 \mathrm{mg}$ of samples were repeatedly (twice) dissolved at $120^{\circ} \mathrm{C}$ in $2 \mathrm{~mL}$ Teflon Savilex ${ }^{\circledR}$ beakers using in $1 \mathrm{~mL}$ $\mathrm{HF}+0.5 \mathrm{~mL} \mathrm{HClO}_{4}$. After total evaporation, samples were diluted 10000 times using $0.5 \mathrm{~N} \mathrm{HNO}_{3}$ and analyzed using both medium and low resolution on the Thermo® using international standards BCR2, BHVO2 and BIR-1 (Li and Lee, 2006). These 
standards demonstrated external reproducibilities better than $5-10 \%$ depending on the element and concentration as documented in Supplementary Table 1. Pb, Hf, Sr and Nd isotope compositions were obtained on single fractions (0.5-1 g of samples) leached for one hour at $100^{\circ} \mathrm{C}$ in $6 \mathrm{~mL}$ of $6 \mathrm{~N} \mathrm{HCl}$, and subsequently dissolved in $3 \mathrm{~mL} \mathrm{HF}+1 \mathrm{~mL}$ $\mathrm{HNO}_{3}$ following the protocol described by Mougel et al. (2014). $\mathrm{Hf}, \mathrm{Nd}$ and $\mathrm{Pb}$ were purified following the protocol of Blichert-Toft et al. (2005) (fluoride centrifugation, and column chromatography). Sr was separated from the Nd fraction using Eichrom Srspecific resin following the protocol by Moynier et al. (2010), adapted from Fietzke and Eisenhauer (2006). Pb, Hf and $\mathrm{Nd}$ isotopes were analysed using a Thermo® Neptune

314 MC-ICP-MS at Ifremer-Brest. Sr isotopes were obtained using a Thermo Triton TIMS 315 at the University of Brest. $2 \sigma$ internal errors for $\mathrm{Hf}$ and $\mathrm{Nd}$ are reported in Table 4 and 316 never exceed the last significant digit (1E-5) in each analysis. External reproducibility 317 of $\mathrm{Pb}$ isotopes is estimated based on the repeated measurements since 2008 of a mixed standard solution and never exceeded $60 \mathrm{ppm}$ for ${ }^{206} \mathrm{~Pb} /{ }^{204} \mathrm{~Pb}, 150 \mathrm{ppm}$ for ${ }^{207} \mathrm{~Pb} /{ }^{204} \mathrm{~Pb}$ and $300 \mathrm{ppm}$ for ${ }^{208} \mathrm{~Pb} /{ }^{204} \mathrm{~Pb}$. Measured values were compared with repeatedly analyzed international standards NBS981 (Todt et al., 1996), JMC475 (Blichert-Toft et al., 1997) and La Jolla48 (Tanaka et al., 2000) shown in Supplementary Table 2. Duplicated Sr, $\mathrm{Nd}, \mathrm{Hf}, \mathrm{Pb}$ isotope analyses of one of our samples (S39E1) are shown in Supplementary Table 3.

\section{Petrographic and geochemical results}

\subsection{Petrographic features and lava classification}

Lava samples were classified according to their position in the Total Alkali-Silica plot (TAS; Le Bas et al., 1986; Fig 3a). With the exception of a trachytic intrusion from V4 (site 29), all of them plot within or near the fields of picrobasalts and basalts $\left(\mathrm{SiO}_{2}=\right.$ 43-53 wt $\%, \mathrm{~K}_{2} \mathrm{O}+\mathrm{Na}_{2} \mathrm{O}=0.1-5 \mathrm{wt} \%$ ). A large majority of them are silica-saturated or -

333 Katsura (1964). Therefore, these samples, which include all the massive or pillowed 334 flows of units V1, V2 and V3, the sills and about half the population of dykes can be 335 termed as tholeiitic or transitional picrites and basalts. Alkali basalts plotting above this 336 boundary include the V4 basaltic flows (site 30) and the other half of the analyzed 337 dykes. Some V3 basalts plot near or slightly above Macdonald and Katsura's (1964) 
boundary (Fig. 3a) and can be considered as transitional, as well as V1 basalts which plot definitively below this limit but display strong enrichments in highly incompatible elements (see below).

Pillowed tholeiitic basalts from V1 unit display groundmass textures ranging from glassy (devitrified) rims to microlitic cores. They are subaphyric, with 4-8 modal\% phenocrysts and microphenocrysts of olivine (mostly altered to smectite and chlorite) and fresh plagioclase ranging in size from 0.1 to $0.5 \mathrm{~mm}$. Their groundmass is variably altered into clays and palagonite-type mineral aggregates. Zeolites and carbonates are found as vesicle- and vein-filling materials.

Picrites and picritic basalts (picrobasalts in Fig. 3a) are much more common in subaerial Vaigat Fm flows (V2) than in the overlying main unit of Svartenhuk Fm (V3). They are highly porphyritic, with up to 60 modal\% centimeter- to millimeter-size olivine phenocrysts, containing occasional magnesiochromite inclusions, and subordinate (and smaller) plagioclase phenocrysts and microphenocrysts. The percentage of olivine phenocrysts and their size tend to decrease together with decreasing $\mathrm{MgO}$ contents of bulk rocks, while the relative abundance of plagioclase increases. Clinopyroxene microphenocrysts are uncommon in picrites, and this mineral follows plagioclase in the crystallization sequence of V2 and V3 lavas. The picritic basalts from these two units are rather similar in thin section. Their groundmass is usually intergranular or microlitic. Neither native iron, nor graphite has been identified in the studied picrites. This suggests a weaker contamination in these samples (originally selected for their primitive features) than that described for some more acidic samples from Disko and Nuussuaq (Larsen and Pedersen, 2009).

Tholeiitic basalts from V2 and V3 are the most common petrographic type encountered in the studied sequences. Their phenocryst contents are highly variable and decrease together with $\mathrm{MgO}$ contents of bulk rocks, from 25-20 modal\% (porphyritic basalts) to less than 5 modal\% (subaphyric basalts). Olivine is followed by calcic plagioclase, and then sometimes by minor amounts of augitic clinopyroxene in their crystallization sequence. Plagioclase phenocrysts dominate over olivine in the most evolved (silica-rich) samples, which are especially common in the Svartenhuk Fm main unit (V3). Clinopyroxene phenocrysts mostly occur in this V3 unit, and are uncommon in V2 basalts. The groundmass of tholeiitic basalts usually display microlitic to intergranular textures. Subdoleritic textures occur in sills and in the cores of thick flows and dykes. 
Post-magmatic mineral associations are commonly found in V2 and V3 tholeiitic picrites and basalts. They occur as vesicle- and vein-fillings, and include a variety of zeolites, carbonates (calcite, Mg-calcite, aragonite, dolomite), and clays (smectites, chlorites).

Alkali basalts from Naqerloq Fm. (V4) and from a number of dykes display microlitic to intergranular groundmass textures. They contain about 10 to 15 modal\% phenocrysts, which are, by order of decreasing abundance, calcic plagioclase (up to 0.5 $\mathrm{cm}$ large), diopsidic clinopyroxene and magnesian olivine. They contain significantly smaller amounts of post-magmatic minerals than V1, V2 and V3 lavas.

The fresh alkali trachyte collected at site 29 (V4 unit) is highly porphyritic, with 40 modal\% centimeter-size sanidine phenocrysts, and lesser amounts of smaller titanomagnetite, olivine and green clinopyroxene phenocrysts. Its groundmass, almost exclusively made of alkali feldspar laths, displays a fluidal texture.

\subsection{Major element trends}

The Loss on Ignition (LOI) values (Table 2) range from $0.58 \mathrm{wt} \%$ to $10 \mathrm{wt} \%$, with an average of $2.8 \mathrm{wt} \%$. These rather high values are accounted for by the common occurrence of post-magmatic water-rich minerals (zeolites and clays) and of carbonates in the studied lavas. The variations of $\mathrm{SiO}_{2}$ and $\mathrm{MgO}$ in the studied basaltic flows (V1 to $\mathrm{V} 4)$ are plotted against their $\mathrm{Ni}, \mathrm{CaO}$ and alkali element contents. The higher $\mathrm{MgO}$ contents of V2 lavas (Table 2) evidence the dominance of picrites ( $\mathrm{MgO}>12 \mathrm{wt} \%)$ and Mg-rich basalts in the Vaigat subaerial flows. An upward increase of $\mathrm{TiO}_{2}$ is also observed in the stratigraphic pile: contents higher than $2 \mathrm{wt} \%$, usually considered typical of High-Ti basalts from Large Igneous Provinces (Pik et al., 1998; Shellnutt and Jahn, 2011), are only observed in some V3 evolved tholeiitic and transitional basalts and in V4 alkali basalts (Table 2). Conversely, all V1 and V2 basalts and a majority of V3 tholeiites are typical Low-Ti basalts $\left(\mathrm{TiO}_{2}<2 \mathrm{wt} \%\right.$, Table 2). Similar features have been reported by (Larsen and Pedersen, 2009) for the Disko and Nuussuaq areas, where the lower Vaigat Fm is exclusively made of Low-Ti basalts while High-Ti lavas occur within the overlying Maligât Fm (lateral equivalent of Svartenhuk Fm according to Escher and Pulvertaft (1995).

Major element variations in the studied sequence are dominated (and largely overprinted) by processes linked to accumulation or removal/fractionation of olivine phenocrysts. Indeed, as shown in Figure 3B, addition or removal of magnesian olivine 
are consistent with the covariation of $\mathrm{CaO}$ and $\mathrm{MgO}$ : olivine-rich picritic basalts are

407 CaO-poor while evolved basalts are $\mathrm{CaO}$-rich. These variations are partly accounted for

408 by local gravitational settling effects involving olivine phenocrysts in thick lava flows

409 or sills. However, such shallow processes during and after emplacement are unlikely to

410 occur in thin pahoehoe units and meter-thick tabular flows which make up most of the

411 Vaigat and Svartenhuk Fms sequences. Therefore, fractional crystallization involving 412 olivine separation/accumulation must have occurred at depth, possibly within thick sills 413 or genuine underlying magma chambers. In addition, the least Mg-rich basalts, mostly 414 sampled from dykes, display a co-linear decrease of $\mathrm{CaO}$ and $\mathrm{MgO}$ (Fig. 3B), that is 415 consistent with concomitant removal/ fractionation of olivine plus augite and/or calcic 416 plagioclase. Such variations might result from differential motions of crystal-rich and 417 crystal-poor liquids during dyke emplacement ("Bagnold effect”, e.g. Komar, 1972), 418 and thus cannot be taken as evidence for deep-seated fractional crystallization involving 419 olivine, augite and plagioclase.

\subsection{Trace element variations}

422 Compatible trace elements $\mathrm{Ni}$, $\mathrm{Co}$ and $\mathrm{Cr}$, which are hosted by olivine and 423 magnesiochromite, display positive correlations with $\mathrm{MgO}$ contents (Fig. 3B). Their 424 contents decrease from picrites to evolved basalts, and their behaviors are mainly 425 controlled by olivine removal/accumulation processes.

426 Incompatible element concentrations vary in a more complex fashion, as 427 illustrated by Rare Earth Element (REE) plots normalized to CI chondrite (Fig. 4). V1 428 transitional basalts display the most fractionated REE patterns and the highest contents 429 in Light REE (LREE; e.g. La, Ce), up to 80 times the primitive mantle (PM). V4 alkali 430 basalts also display fractionated REE patterns, although their LREE enrichment remains 431 lower than that of V1 lavas. V2 and V3 REE patterns are fan-shaped, and display 432 variable enrichments in LREE, those of picritic samples being the lowest. The REE 433 patterns of dykes are also fan-shaped, and they encompass the variability found within 434 lava flows (Fig. 4). Alkali basaltic dykes show fractionated patterns and LREE 435 enrichments similar to those observed for V4 alkali basaltic flows. A second family of 436 dykes (and the analyzed sills) has rather flat patterns which resemble those of picrites; 437 and a third dyke family shows moderately LREE enriched patterns similar to those of 438 V2 and V3 evolved tholeiitic basalts. Large Ion Lithophile Elements (LILE: Cs, Rb, Ba, 439 Sr) display somewhat erratic behaviors, with highly variable enrichments or depletions 
440 generating positive or negative spikes in incompatible multi-element patterns 441 normalized to the primitive mantle (Figure 4B). Given the high solubility of these 442 elements into water, such variations can be considered as post-magmatic and attributed 443 to alteration by surface waters and/or percolation of hydrothermal fluids through the 444 studied lava piles. The elements less affected by post-magmatic processes (ie rare earth 445 elements, high field strength elements...) define patterns similar to that of typical OIB 446 (Fig. 5).

447 Highly incompatible elements (e.g. Th and La) versus $\mathrm{MgO}$ (not shown) in V2 448 and V3 lavas define a rough negative correlation (not shown) consistent with the 449 "dilution" of incompatible elements in bulk rocks as a result of accumulation of 450 incompatible element-poor olivine phenocrysts in picritic and Mg-rich lavas. Compared 451 to V2 and V3, V4 alkali basalts and alkaline dykes display higher Th and La contents 452 (Fig. 4) consistent with their more fractionated REE and multi-element patterns, as well 453 as higher $\mathrm{Nb} / \mathrm{La}$ ratios (Fig. 5). These features might indicate either lower degrees of 454 partial melting, or a more incompatible element enriched source (with respect to V2 and 455 V3 ones), or a combination of both. Finally, despite their transitional character, some $456 \mathrm{~V} 1$ pillowed lavas (together with a few dykes) show the highest $\mathrm{La}$, Th and $\mathrm{Pb}$ contents 457 found in the studied lava sequence (Figs. 4 and 5), and consistent with their highly 458 fractionated REE and multi-element patterns. Once again, these features could be 459 attributed to a more enriched source, lower degrees of melting, or both.

\section{4. $\mathrm{Sr}, \mathrm{Nd}, \mathrm{Pb}$ and $\mathrm{Hf}$ isotopes}

Lead isotopes define two distinct trends (Figs. 6 and 7). ${ }^{208} \mathrm{~Pb} /{ }^{204} \mathrm{~Pb}$ range from 46336.7 to $39,{ }^{207} \mathrm{~Pb} /{ }^{204} \mathrm{~Pb}$ from 15 to 15.5 and ${ }^{206} \mathrm{~Pb} /{ }^{204} \mathrm{~Pb}$ from 16.13 to 19.26 . A principal 464 component analysis calculated on these $\mathrm{Pb}$ isotopes reveals the existence of only two 465 significant principal components (the first one accounting for $94.2 \%$ of the total 466 variability, principal component 2 for about 5.3\%, and principal component 3 is 467 insignificant). This result indicates that a mixture of three end-members is sufficient to 468 explain the isotope variability in this area (Blichert-Toft et al., 2005). Hafnium isotopes 469 are scattered as well, and feature both radiogenic and unradiogenic signatures $470 \quad\left({ }^{176} \mathrm{Hf} /{ }^{177} \mathrm{Hf}\right.$ from 0.28247 to $0.2832 ; \varepsilon_{\mathrm{Hf}}=-10.81$ to +15.95$)$. They also define a three 471 end-members-pattern corresponding to two distinct mixing trends (Fig. 6). Nd isotopes correlate with Hf data ranging from ${ }^{143} \mathrm{Nd} /{ }^{144} \mathrm{~N}=0.51222 \quad\left(\varepsilon_{\mathrm{Nd}}=-8.15\right)$ to 
${ }^{143} \mathrm{Nd} /{ }^{144} \mathrm{~N}=0.51309\left(\varepsilon_{\mathrm{Nd}}=8.9\right)$. Even if most of the samples have "mantle-like" $\mathrm{Sr}$ 474 isotopic compositions $\left({ }^{87} \mathrm{Sr} /{ }^{86} \mathrm{Sr}<0.704\right)$, 16 of them display significantly more 475 radiogenic $\mathrm{Sr}$ signatures (up to ${ }^{87} \mathrm{Sr} /{ }^{86} \mathrm{Sr}=0.708$ ). Ten out of those 16 samples also have 476 unradiogenic $\mathrm{Pb}\left({ }^{206} \mathrm{~Pb} /{ }^{204} \mathrm{~Pb}<17\right)$, and trace element patterns (low $\mathrm{Nb}$, Ta and high $\mathrm{Pb}$ 477 contents, Fig. 5) typical of continental crust contamination (Rudnick and Fountain, 478 1995; Rudnick and Gao, 2003). These samples include all of those collected from the 479 basal unit V1.

480 The two mixing trends identified in $\mathrm{Sr}, \mathrm{Pb}$ and $\mathrm{Hf}$ isotope spaces, are also visible 481 on diagrams using isotopic and REE ratios (e.g., ${ }^{206} \mathrm{~Pb} /{ }^{204} \mathrm{~Pb}, \mathrm{La} / \mathrm{Sm}, \mathrm{Sm} / \mathrm{Yb}$ and $\mathrm{La} / \mathrm{Yb}$, 482 Fig. 8). They are also related to the stratigraphic position of the samples, i.e. their height 483 within the lava pile. Indeed, all the samples from basal units V1 and V2 lie within the 484 same trend (Figs. 6 and 7) connecting a component "Sk1" (with low ${ }^{207} \mathrm{~Pb} /{ }^{204} \mathrm{~Pb}$ and 485 "intermediate" ${ }^{208} \mathrm{~Pb} /{ }^{204} \mathrm{~Pb}$ ) to a moderately high ${ }^{208} \mathrm{~Pb} /{ }^{204} \mathrm{~Pb}$ and ${ }^{206} \mathrm{~Pb} /{ }^{20} 4 \mathrm{~Pb}$ component 486 "Sk2". Complementarily, all samples from units V3 and V4, together with those from 487 sills and dykes, plot along a trend connecting "Sk2" to a component "Sk3" (with high 488 ${ }^{208} \mathrm{~Pb} /{ }^{204} \mathrm{~Pb},{ }^{207} \mathrm{~Pb} /{ }^{204} \mathrm{~Pb}$ and ${ }^{206} \mathrm{~Pb} /{ }^{204} \mathrm{~Pb}$ ).

\section{Discussion}

\subsection{Trace element and isotopic evidence for a minor role of crustal contamination}

The highly incompatible elements $\mathrm{Nb}$ and $\mathrm{Ta}$ display positive or negative peaks in multi-element patterns (Fig. 4B) which are unlikely of post-magmatic origin considering the insoluble character of these High Field Strength Elements (HFSE). $\mathrm{Nb} / \mathrm{La}$ ratios show a tentative negative correlation with $\mathrm{SiO}_{2}$, whereas $\mathrm{Pb}$ contents are positively correlated with silica for V1 and V2 lavas (Fig. 5). These features likely reflect crustal contamination effects in these two lowermost units, since silica-rich continental crust is selectively depleted in $\mathrm{Nb}$ and $\mathrm{Ta}$ and enriched in $\mathrm{Pb}$ with respect to elements of similar incompatibility, e.g. La (Tang et al, 2019 and references therein).. et al., 1992), or any North Atlantic volcanic rocks. Its radiogenic Sr, unradiogenic Hf and $\mathrm{Nd}$, as well as the low $\mathrm{Nb}, \mathrm{Ta}$, and high $\mathrm{Pb}$ contents (Fig. 5) of lavas plotting close

504 to it (Figs. 6 and 7) suggest that the origin of this component is related to continental 505 crust contamination of mantle-derived melts by materials similar in composition to 
506 Greenland basement late Archean orthogneisses and granodiorites analyzed by Larsen

507 and Pedersen (2009). The fact that these contamination effects are limited to the oldest

508 units V1 and V2 is consistent with the hypothesis of an uprise of the younger melts

509 (constituting units V3 and V4) through a plumbing system coated with earlier basaltic

510 lavas (e.g. Arndt and Christensen, 1992) or exhausted of fertile material by previous

511 melting events (e.g. Meade et al, 2014).

\subsection{Partial melting conditions}

$514 \mathrm{Si}$ and $\mathrm{Mg}$ contents can be used as proxies in order to estimate pressure and temperature of melt extraction in the mantle (Lee et al., 2009). Only a limited number of

516 samples are "primitive enough" (i.e. experienced only olivine fractionation), to 517 adequately estimate their pristine major element concentrations by simple olivine 518 addition (Albarède, 1992; Lee et al., 2009). Moreover, some of them, with $\mathrm{MgO}$ 519 contents $>15 \mathrm{wt} \%$, need to be afterwards corrected for olivine accumulation (back to 520 equilibrium with their olivine phenocrysts Mg\# 0.83, Supplementary Table 4) and 521 olivine fractionation (back to equilibrium with olivine of mantle-like composition $522 \mathrm{Mg \#} \mathrm{0.89).} \mathrm{Thermobarometric} \mathrm{estimates} \mathrm{thus} \mathrm{obtained} \mathrm{on} \mathrm{ten} \mathrm{samples} \mathrm{from} \mathrm{units} \mathrm{V2}$ 523 and V3 suggest temperatures and pressures of $\sim 1350 \pm 100{ }^{\circ} \mathrm{C}$ and $2.5 \pm 0.5 \mathrm{GPa}$, 524 respectively. These results, although consistent with those recently reported by Hole and 525 Natland (2019), need to be considered with caution, given the number of 526 approximations in the thermobarometric approach, as well as uncertainties concerning 527 the precise geological setting at that time (crustal thickness). The estimated temperature 528 range suggests that the mantle beneath Svartenhuk was not very hot compared with 529 other published evaluations for the NAIP (e.g. 1480-1550 ${ }^{\circ} \mathrm{C}$, Hole and Millett, 2016; 530 see also Herzberg et al. 2007 and references therein). Our estimated P-T conditions 531 overlap the spinel/garnet transition zone in the mantle $\left(2.2 \mathrm{GPa}\right.$ at $1300{ }^{\circ} \mathrm{C}$, O'Neill, 532 1981; Robinson and Wood, 1998), and it is therefore probable that Svartenhuk Fm. 533 lavas were extracted from melting columns involving both garnet- and spinel-bearing 534 peridotites, as often proposed for NAIP magmas (Kerr, 1994; Kerr et al, 1999; Saunders et al., 2007; Hole and Millett, 2016).

Even if the "fan-shaped" rare earth elements (REE) patterns observed on figure 4 537 are partly the result of different rates of partial melting, LREE/HREE fractionation can 538 also be accounted for by the presence of residual garnet in the source (e.g. Frey et al. 539 1978, Thirlwall et al.,1994). In figure 8 plots, $\mathrm{Pb}$ isotopes, $\mathrm{La} / \mathrm{Sm}$ and $\mathrm{Sm} / \mathrm{Yb}$ ratios are 
540 compared with the average slope of REE spectra quantified by $\mathrm{La} / \mathrm{Yb}$ ratios. The upper 541 diagram $\left({ }^{206} \mathrm{~Pb} /{ }^{204} \mathrm{~Pb}\right.$ vs $\mathrm{La} / \mathrm{Yb}$ ) reflects the effects of crustal contamination (units $\mathrm{V} 1$ 542 and V2) on geochemical compositions (see section 5.1). The middle diagram documents 543 the concomitant effects of crustal contamination and degrees of partial melting on 544 LREE/intermediate REE relative abundances. The lower plot provides insights 545 concerning the amount of garnet-bearing peridotites involved in the melting column. 546 Altogether, these three diagrams suggest that: i/ Lavas derived from rather high degrees of partial melting all belong to units V2 and V3. Basalts from units V1 and V4 were generated by smaller degrees of mantle melting (as suggested by their alkali to transitional signatures in Figs. 4 and 5). Precise amounts of melting are difficult to assert considering the uncertainties concerning the initial composition(s) of mantle source(s). Nevertheless, models of garnet- (shown in red) and spinel-bearing (shown in green) batch lherzolite melting (see Gurenko and Chaussidon, 1995 for details on initial compositions, McKenzy and O'nion, 1991 for partition coefficients; and Thirlwall et al.1993 for mineral proportions in the melting) show that V1 and V4 lavas would are derived from melting degrees lower than 5\%, and most V2 and V3 lavas from clearly higher ones (Fig. 8).

ii/ On average, basalts from units V2 and V3 feature $\mathrm{Sm} / \mathrm{Yb}$ ratios $50 \%$ lower than those of samples from units V1 and V4. This stronger fractionation between intermediate and heavy REE in V1 and V4 suggests a larger involvement of garnet peridotites (and therefore greater melting depths) at the beginning and the end of the magmatic history than during the emplacement of the main V2-V3 volcanic sequences. These results are in agreement with previous petrogenetic studies of West Greenland picritic and Mg-rich basalts demonstrating that their main sequences derived predominantly from spinel-bearing peridotites (Gill et al., 1991; Ryabchikov et al., 1998; Larsen and Pedersen, 2000, 2009).

Therefore, we propose that small degrees of melting leading to V1 lavas were initiated at depths greater than $75 \mathrm{~km}$ below a relatively thick lithosphere. Subsequently, these melts propagated upwards into the spinel peridotite zone in connection with

571 forming V2 and V3 lavas. Finally, the melting zone deepened again, and melting rates 572 decreased, thereby generating V4 alkali basalts. 


\subsection{Mantle source heterogeneity and its temporal evolution}

The isotope diversity reported in this study covers a range similar to that previously reported for the neighboring Disko Island (Larsen and Pedersen, 2009) and the only differences concern the extent of crustal contamination (Fig. 5). The least contaminated samples (identified on Figs. 5 and 8) also largely overlap with samples from Iceland and the adjacent ridges, as well as with those from East Greenland (figs. 6 and 7). The isotopic diversity within the Iceland plume has been widely discussed (Chauvel and Hémond, 2000; Thirlwall et al., 2004; Kokfelt et al., 2006; Maclennan, 2008; Kitawaga et al., 2008) and is denoted in figure 7 by both depleted (D, Kitawaga et al., 2008; ID-1 and ID-2, Thirlwall et al., 2004), and enriched (E-1and E-2, Kitawaga et al., 2008; IE-1 and IE-2, Thirlwall et al., 2004) Icelandic internal components (Fig. 7). In figures 6 and 7, $\mathrm{Hf}, \mathrm{Sr}$ and $\mathrm{Pb}$ compositions of component "Sk2" are very similar to those of OIB and E-MORB related to the Iceland hotspot, and more especially to a mixture of the Icelandic inner components "D" (for depleted) and "E-1" (for Enriched 1) of Kitawaga et al. (2008) or "ID1" - "ID2" (for Iceland Depleted 1 and 2) and "IE1" (for Iceland enriched 1) of Thirlwall et al. (2004).

Alternatively, Sk3 seems to correspond to the Iceland E-2 enriched component of Kitagawa et al. (2008) (or "IE-1" of Thirlwall et al., 2004) that point toward the common component C (Hanan and Graham, 1996) in all isotope spaces. This enriched component has been proposed to be intrinsic to the Icelandic hotspot (Hanan and Schilling, 1997; Kitawaga et al., 2008; Thirlwall et al., 2004; Peate et al., 2010). The presence of distinct Icelandic isotopic components has also been described in Eastern Greenland (Barker et al., 2006). Nevertheless, in that region, the different signatures appear in separate areas (Milne, Rømer and Skræterne), located hundreds of kilometers away from each other. In the present study, we report distinct signatures on samples all coming from a restricted segment ( $<40 \mathrm{~km}$ along the coast) and covering a time span shorter than 8 m.y. Such diversity can therefore hardly be imagined as the result of the tapping of distinct parts of an Iceland type mantle plume. Instead, we suggest that the Sk3 signature in our dataset corresponds to a trend toward the $\mathrm{C}$ component of Hanan and Graham (1996). This component has been recognized as being widely disseminated within the upper mantle feeding the Arctic segments of the mid-Atlantic ridges and is therefore believed to correspond to an ubiquitous ingredient of the North Atlantic upper mantle (Blichert-Toft et al., 2005). 

Svartenhuk samples and Iceland plume geochemical signatures. Indeed, Fitton et al.

609 (1997) used the comparison of $\mathrm{Nb} / \mathrm{Y}$ and $\mathrm{Zr} / \mathrm{Y}$ in order to decipher whether the 610 magmatic sources of basalts are more likely related to the Iceland plume or to the 611 neighboring MORB mantle. They proposed a $\Delta \mathrm{Nb}$ index $=1.72+\log (\mathrm{Nb} / \mathrm{Y})$ -

$6121.92 \log (\mathrm{Zr} / \mathrm{Y})$; where $\Delta \mathrm{Nb}$ is negative in MORB samples, but positive in Iceland 613 plume-derived material. Even if this approach has been criticized as possibly biased by 614 differences in pressures of melting (Hanan et al., 2000; Stracke et al., 2003), it is worth 615 noting that most samples from this study feature positive $\Delta \mathrm{Nb}$ values. Indeed, in Figure 6169 , only some samples from units V2 and V3 display negative $\Delta \mathrm{Nb}$ (Fig. 9), suggesting 617 that the contribution of Icelandic material in lava sources was lower during these 618 intermediate stages than during the emplacement of the earliest and latest V1 and V4 619 units. Moreover, a plume imprint on geochemical signatures of Svartenhuk lavas is also 620 consistent with the extremely primitive helium isotopic compositions recently published 621 by Péron et al. (2018) for olivines from our V3 samples S33E7 and S35E7 (R/Ra=31.0 and 34.9, respectively), similar to those previously reported for samples from Disko Island and Baffin Island (Graham et al., 1998; Jackson et al., 2010).

Altogether, these features suggest that the Sk2-Sk3 trend (common to both V3 and 625 V4 units) could be accounted for by a mixture of Icelandic-type material (Sk2) and a 626 mixed ambient upper mantle reservoir $(\mathrm{Sk} 3)$. The respective proportions of these two 627 components appear to evolve through time, since only samples coming from unit V3 628 carry isotope signatures suggesting the involvement of significant amounts of C-like material, whereas the uppermost V4 lavas seem to tap preferentially Iceland hotspot material. Furthermore, even if geochemical signatures of V1 and V2 are partly

631 controlled by crustal contamination, they also point solely toward the Iceland-like 632 signature. This sequence of magmatic events is summarized in figures 10 (petrogenetic 633 constraints) and 11 (speculative tectonic interpretation). During the emplacements of 634 basal units V1 and V2 (61 to 59.5 Ma old, Chauvet et al., accepted), initially low, but 635 temporally increasing degrees of melting of enriched Icelandic plume material 636 (displaying Sk2 isotopic signatures) generated basaltic melts at depths starting beneath $63775 \mathrm{~km}$, and these magmas were contaminated during their ascent through the continental 638 crust. During V3 emplacement (59.5-57.7 Ma), the melting process affected a wider 639 range of lithologies in the spinel stability field and propagated to neighboring 
640 (shallower) materials from the upper mantle (involving material displaying component

641 Sk3 isotope signatures), with little or undetectable crustal contamination. Finally, during

642 V4 emplacement, i.e. between 57.7 and 53.3 Ma (Chauvet et al., accepted), the melting

643 zone deepened again and was once more mostly restricted to the enriched mantle

644 material (Figs. 10 and 11).

645

\subsection{Baffin Bay breakup and tectonic controls of mantle melting}

647 This sequence of events as reported by combining geochemical and tectonic data can be interpreted as the progressive initiation of decompression melting of an upwelling mantle below a progressively thinning lithosphere in a continental extension setting

650 (Fig. 11). The thinning observed between the emplacement of V1 and V2-V3 lavas

651 likely results from a combination of the tectonic stretching of the upper part of the

652 lithosphere and of the thermal erosion of its base by convecting hot mantle (Fig. 11).

653 Such a combination has been proposed as an explanation of the magmatic history of

654 Mull and Skye islands (Kerr, 1994; Kerr et al., 1999; Saunders et al., 1997). In these

655 islands, as well as in Giant's Causeway basalts (Barrat and Nesbitt, 1996), temporally

656 increasing melting rates and decreasing melting pressures similar to those described

657 in Svartenhuk are observed, despite rather different tectonic contexts characterized by

658 lower extension rates (Meyer et al., 2007). A temporal decrease of lithospheric

659 thickness seems the most likely factor controlling such changes in NAIP basaltic

660 magma compositions (Ellam, 1992; Kerr, 1994).

661 The decreasing involvement of the ambient mantle (component Sk3) contribution from 662 V3 to V4 (Fig. 10), and the concomitant deepening and decrease of partial melting rates 663 (back to alkali basaltic compositions) in this most proximal part of the volcanic margin, 664 may be (at least partly) attributed to the gradual westward shift of extension with time

665 (Geoffroy et al., 2015; Chauvet et al., accepted). Indeed, the innermost Svartenhuk 666 margin progressively became passive although extension still continued (as attested by 667 syn-tectonic control of V4 emplacement), albeit at lower rates (Chauvet et al, accepted). 668 It is also possible that the accumulation beneath the lithosphere of refractory mantle 669 residues left after melt extraction blocked the ascent of hot and fertile mantle sources 670 and resulted in deeper, lower-degree melting as previously suggested for East Greenland 671 flood basalts (Fram and Lesher, 1993, 1997). 

Svartenhuk peninsula allow us to document the c. 7 m.y. long volcanic activity accompanying the continental thinning process that preceded the Eocene opening of

677 Baffin Bay, the chronological and tectonic aspects of which are discussed in a 678 companion paper (Chauvet et al., accepted). The sequence of magmatic events started 679 with (i) the deep (>75 km) low degree partial melting of an Iceland plume-like source, 680 followed by (ii) shallower and higher degrees of melting of a mixture of Iceland hotspot 681 and "ambient upper mantle" materials, and finally ended with (iii) lower degrees of 682 melting of a deeper source dominated again by Icelandic-type signatures. The first melting event could have been triggered by the adiabatic ascent of the Iceland plume 684 below a 75-km-thick lithosphere, inherited from the previous Mesozoic extension. The 685 OIB-type signature of V1 lavas is clear despite the crustal contamination processes that 686 they experienced during their ascent. The following melting events (V2 to V3 lavas) 687 occurred at decreasing pressures and were coeval with syn-magmatic extension in the 688 upper crust (Chauvet et al., accepted) and therefore a subsequent reduction in 689 lithosphere thickness (Figs. 10 and 11). Thus, V2-V3 melts were a direct consequence 690 of the convective upwelling of Icelandic OIB-type mantle in the necked sub-lithospheric 691 area (Boutiller and Keen, 1999), associated with lithospheric thinning resulting from a 692 combination of tectonic stretching and thermal erosion of the Svartenhuk lithosphere. 693 The later decrease in magmatic activity (emplacement of V4 lavas) was concomitant 694 with a progressive focusing of syn-magmatic strain towards the central axis of the proto-Baffin Bay during the Eocene. This shift in extension was likely accompanied by a progressive cooling (and thus, thickening) of the proximal W-Greenland lithosphere over a still convecting asthenosphere. The combined decrease in melting rates and the return to enriched source materials suggest a further deepening of the melting zone, possibly linked to the accumulation beneath the lithosphere of refractory mantle residues.

\section{Acknowledgments}

This study is part of the Petrobras-UBO Volcabasin program. The field work was carried out during a five-week expedition in the summer of 2012 and benefited from the

705 logistic support of the research vessel Porsild from the Arctic Station in Godhavn

706 (Greenland) and the French polar yacht Vagabond. Philippe Nonnotte's help was

707 especially appreciated before and during the fieldwork in Greenland. We also thank the 
Vagabond family, who provided pleasant and efficient assistance, both at sea and in the field. AA and RCM thank Claire Bassoullet, Philippe Nonnotte, Céline Liorzou and

Bleuenn Gueguen for their help during the analytical work. AA thanks David Graham and Barry Hanan for insightful discussions. We are grateful to Elishevah Van Kooten for her careful reading. The manuscript was considerably improved following the suggestions of Editor A.C. Kerr and the thorough reviews of Drs. R. Gooday and N. Arndt.

\section{References}

Abdelmalak, M.M, Geoffroy, L., Angelier, J., Bonin, B., Callot, J.P., Gelard, J.P., melting mantle: A case example in West Greenland. Tectonophysics 581, 132143.

Abdelmalak, M.M, Planke, S., Polteau, S., Hartz, E.H., Faleide, J.I., Tegner, C., Jerram, D.A., Millett, J.M., Myklebust, R., 2018. Breakup volcanism and plate tectonics in the NW Atlantic. Tectonophysics in press, doi.org/10.1016/j.tecto.2018.08.002

Agranier, A., Blichert-Toft, J., Graham, D., Debaille, V., Schiano, P., Albarede, F., 2005. The spectra of isotopic heterogeneities along the mid-Atlantic Ridge. Earth Planet. Sci. Lett. 238, 96-109.

Albarède, F., 1992. How deep do common basaltic magmas form and differenciate. J. Geophys. Res.-Solid Earth 97, 10997-11009.

Arndt, N., Christensen, U., 1992. The role of lithospheric mantle in continental flood volcanism - thermal and geochemical constraints. J. Geophys. Res.-Solid Earth 97, 10967-10981.

Barrat, J.A., Nesbitt, R.W., 1996. Geochemistry of the tertiary volcanism of Northern Ireland. Chem. Geol. 129, 1-2, 15-38.

Barrat, J. A., Yamaguchi, A., Greenwood, R. C., Bohn, M., Cotten, J., Benoit, M., Franchi, I.A., 2007. The Stannern trend eucrites: Contamination of main group eucritic magmas by crustal partial melts. Geochim. Cosmochim. Acta, 71, 16, 4108-4124

Barker, A. K., Baker, J. A., Peate, D., W., 2006. Interaction of the rifting East Greenland margin with a zoned ancestral Iceland plume. Geology 34, 481-484.

Blichert-Toft, J., Agranier, A., Andres, M., Kingsley, R., Schilling, J., Albarède, F., 2005. Geochemical segmentation of the Mid-Atlantic Ridge north of Iceland and ridge-hot spot interaction in the North Atlantic. Geochem. Geophys. Geosystems 6. https://doi.org/10.1029/2004GC000788

Blichert-Toft, J., Chauvel, C., Albarede, F., 1997. Separation of Hf and Lu for highprecision isotope analysis of rock samples by magnetic sector multiple collector ICP-MS. Contrib. Mineral. Petrol. 127, 248-260.

Block, M., Damm, V., Ehrhardt, A., Berglar, K., Schnabel, M., Altenbernd, T., 2012. Characteristics of the West Greenland Margin in the Southern Baffin Bay. 74th EAGE Conference \& Exhibition, Abstract, 10.3997/2214 4609.20148225.

Boutiller, R.R., Keen, C.E., 1999. Small-scale convection and divergent plate boundaries. J. Geophys. Res.-Solid Earth 104, B4, 7389-7403. 
Breddam, K., 2002. Kistufell: Primitive melt from the Iceland mantle plume. Journal of Petrology 43, 2, 345-373.

Callot, J.-P., 2002. Origine, structure et developpement des marges volcaniques: l'exemple du Groenland. Univerité Paris 6, Ecole Normale Supérieure.

Caroff, M., Maury, R.C., Cotten, J., Clément, J.P., 2000. Segregation structures in vapor-differentiated basaltic flows. Bull. Volcanol. 62, 171-187.

Chalmers, J.A. and Laursen, K.H., 1995. Labrador Sea - the extent of continental and oceanic-crust and the timing of the onset of sea-florr spreading. Marine Petroleum Geology 12, 2, 205-217.

Chalmers, J.A. and Puvertaft, T.C.R., 2001. Development of the continental margins of the Labrador Sea: a review. Geol. Soc. Special Pub. 187, 77-105.

Chauvel, C., Hemond, C., 2000. Melting of a complete section of recycled oceanic crust: Trace element and $\mathrm{Pb}$ isotopic evidence from Iceland. Geochem. Geophys. Geosystems 1, 1001. https://doi.org/10.1029/1999GC000002

Chauvet, F., Geoffroy, L., Guillou, H., Maury, R.C., Le Gall, B., Agranier, A., Aviana, A., accepted. Eocene continental breakup in Baffin Bay. Tectonophysics

Coffin, M.F., Eldholm, O., 1994. Large Igneous provinces - crustal structure, dimensions, and external consequences. Reviews Geophysics 32, 1-36.

Cotten, J., Le Dez, A., Bau, M., Caroff, M., Maury, R., Dulski, P., Fourcade, S., Bohn, M., Brousse, R., 1995. Origin of anomalous rare-Earth element and Yttrium enrichments in subaerially exposed basalts, evidence from French Polynesia. Chem. Geol. 119, 115-138.

Courtillot, V., Jaupart, C., Manighetti, I., Tapponnier, P., Besse, J., 1999. On causal links between flood basalts and continental breakup. Earth Planet. Sci. Lett. 166, 3-4, 177-195.

Eggins, S.M., Woodhead, J.D., Kinsley, L.P.J., Mortimer, G.E., Sylvester, P., McCulloch, M.T., Hergt, J.M., Handler, M.R., 1997. A simple method for the precise determination of $>=40$ trace elements in geological samples by ICPMS using enriched isotope internal standardisation. Chem. Geol. 134, 4, 311-326.

Ellam, R.M., 1992. Lithospheric thickness as a control on basalt geochemistry. Geology, 20, 2, 153-156.

Escher, J.C., Pulvertaft, T.C.R., 1995. Geological map of Greenland, 1:2 500000. Geol. Surv. Greenl.

Fietzke, J., Eisenhauer, A., 2006. Determination of temperature-dependent stable strontium isotope ( $\mathrm{Sr}-88 / \mathrm{Sr}-86)$ fractionation via bracketing standard MC-ICPMS. Geochem. Geophys. Geosystems 7, Q08009. https://doi.org/10.1029/2006GC001243

Fitton, J.G., Saunders, A.D., Norry, M.J., Hardason, B.S., Taylor, R.N., 1997. Thermal and chemical structure of the Iceland plume. Earth Planet. Sci. Lett. 153, 3-4, 197-208.

Francis, D.,1985. The Baffin-Bay lavas and the value of picrites as analogs of primary magmas. Contrib. Mineral. Petrol., 89, 2-3, 144-154.

Fram, M.S., Lesher, C.E., 1993. Geochemical constraints on mantle melting during creation of the North-Atlantic basin. Nature 363, 6431, 712-715.

Fram, M.S., Lesher, C.E., 1997. Generation and polybaric differentiation of East Greenland early tertiary flood basalts. Journal of Petrology 38, 2, 231-275.

Frey, F.A., Green, D.H., Roy, S.D., 1978. Integrated models of basalt petrogenesis: a study of quartz tholeiites to olivine melilites from south eastern Australia 
utilizing geochemical and experimental petrological data. Journal of Petrology 19, 463-513.

Funck, T., Gohl, K., Damm, V., Heyde, I., 2012. Tectonic evolution of southern Baffin Bay and Davis Strait: Results from a seismic refraction transect between Canada and Greenland. J. Geophys. Res. 117, B04107.

Geoffroy, L., 2005. Volcanic passive margins. C. R. Geoscience 337, 1395-1408.

Geoffroy L., Burov, E.B., Werner, P., 2015. Volcanic passive margins: another way to break up continents. Scientific Reports 5, 14828, DOI: 10.1038/srep14828.

Geoffroy, L., Callot, J.P., Scaillet, S., Skuce, A.S., Gélard, J.-P., Ravilly, M., Angelier, J., Bonin, B., Cayet, C., Perrot-Galmiche, K., Lepvrier, C., 2001. Southeast Baffin volcanic margin and the North American-Greenland plate separation. Tectonics 20, 566-584.

Gill, R.C.O., Pedersen, A.K., Larsen, J.G., 1991. Tertiary picrites in West Greenland: Melting at the periphery of a plume?, in: Magmatism and the Causes of Continental Break-Up. Programme and Abstracts. p. 13.

Gurenko, A.A., Chaussidon, M., 1995. Enriched and depleted primitive melts included in olivine from Icelandic tholeiites - origin by continuous melting of a single Mantle column. Geochim. Cosmochim. Acta 59, 14, 2905-2917.

Graham, D.W., Larsen, L.M., Hanan, B.B., Storey, M., Pedersen, A.K., Lupton, J.E., 1998. Helium isotope composition of the early Iceland mantle plume inferred from the Tertiary picrites of West Greenland. Earth Planet. Sci. Lett. 160, 241255.

Hanan, B.B., Blichert-Toft, J., Kingsley, R., Schilling, J.G., 2000. Depleted Iceland mantle plume geochemical signature: artifact of multicomponent mixing? Geochem. Geophys. Geosystems 1, 1003, http://doi:10.1029/1999GC000009.

Hanan, B.B., Graham, D.W., 1996. Lead and helium isotope evidence from oceanic basalts for a common deep source of mantle plumes. Science 272, 991-995.

Hanan, B.B., Schilling, J.G., 1997. The dynamic evolution of the Iceland mantle plume: the lead isotope perspective. Earth Planet. Sci. Lett. 151, 43-60.

Hart, S., Hauri, E., Oschmann, L., Whitehead, J., 1992. Mantle plumes and entrainment - isotopic evidence. Science 256, 517-520.

Herzberg, C., Asimow, P.D., Arndt, N., Niu, Y.L., Lesher, C.M., Fitton, J.G., Cheadle, M.J., Saunders, A.D., 2007. Temperatures in ambient mantle and plumes: Constraints from basalts, picrites, and komatiites. Geochem. Geophys. Geosystems 8, Q02006. https://doi.org/10.1029/2006GC001390

Hole, M.J., Millett, J.M., 2016. Controls of Mantle Potential Temperature and Lithospheric Thickness on Magmatism in the North Atlantic Igneous Province. Journal of Petrology 57, 2, 417-436.

Hole, M.J., Natland, J.H., 2019. Magmatism in the North Atlantic Igneous Province; mantle temperatures, rifting and geodynamics. Earth-Science Reviews, in press, https://doi.org/10.1016/j.earscirev.2019.02.011

Holm, P.M., Gill, R.C.O , Pedersen, A.K., Larsen, J.G., Hald, N., Nielsen, T.F.D., Thirlwall, M.F., 1993. The Tertiary picrites of West Greenland - contribution from Icelandic and other sources. Earth Planet. Sci. Lett. 115, 1-4, 227-244.

Hosseinpour, M., Müller, R.D., Williams, S.E., Whittaker J.M., 2013. Full-fit reconstruction of the Labrador Sea and Baffin Bay. J. Geophys. Res. -Solid Earth 4, 461-479.

Jackson, M.G., Carlson, R.W., Kurtz, M.D., Kempton, P.D., Francis, D., Blusztajn, J., 2010. Evidence for survival of the oldest terrestrial mantle reservoir. Nature 466, 853-856, doi:1.138/nature09287. 
Jerram, D.A., 2002. Volcanology and facies architecture of flood basalts. Geological Society of America Special Papers 362, 119-132 .

Kerr, A.C. 1994, Lithospheric thinning during the evolution of continental large igneous provinces - a case study from the North-Atlantic Tertiary province. Geology 22, 11, 1027-1030.

Kerr, A.C., Kent, R.W., Thomson, B.A., Seedhouse, J.K., Donaldson, C.H., 1999. Geochemical evolution of the Tertiary Mull volcano, Western Scotland. Journal of Petrology 40, 6, 873-908.

Kitawaga, H., Kobayashi, K., Makishiama, A., Nakamura, E., 2008. Multiple pulses of the mantle plume: evidence from tertiary Icelandic lavas. Journal of Petrology 49, 7, 1365-1396.

Kokfelt, T.F., Hoernle, K., Hauff, F., Fiebig, J., Werner, R., Garbe-Schonberg, D., 2006. Combined trace element and $\mathrm{Pb}, \mathrm{Nd}, \mathrm{Sr}, \mathrm{O}$ isotope evidence for recycled oceanic crust (upper and lower) in the Iceland mantle plume. Journal of Petrology 47, 9, 1705-1749.

Kokfelt, T.F., Hoernle, K., Lundstrom, C., Hauff, F., Van den Bogaard, C., 2009. Time-scales for magmatic differentiation at the Snaefellsjokull central volcano, western Iceland: Constraints from U-Th-Pa-Ra disequilibria in post-glacial lavas. Geochim. Cosmochim. Acta 73, 4, 1120-1144.

Komar, P.D. 1972. Mechanical interactions of phenocrysts and flow differentiation of igneous dikes and sills. Geol. Soc. Am. Bull. 83, 973-988

Kuritani, T., Yokohama, T., Kitawaga, H., Kobayashi, K., Nakamura, E., 2011. Geochemical evolution of historical lavas from Askja Volcano, Iceland: Implications for mechanisms and timescales of magmatic differentiation. Geochim. Cosmochim. Acta 75, 2, 570-587.

Larsen, J.G., 1983. Geologisk kort over Grønland, 1:100 000, Igdlorssuit, 71 V.1 Syd. København: Grønlands Geologiske Undersøgelse (English legend).

Larsen, J.G., Grocott, J., 1992. Geologisk kort over Grønland, 1:100 000, Svartenhuk, 71 V.1 Nord. København: Grønlands Geologiske Undersøgelse (English legend).

Larsen, L.M., Pedersen, A.K., 2000. Processes in high-Mg, high-T magmas: Evidence from olivine, chromite and glass in palaeogene picrites from West Greenland. Journal of Petrology 41, 1071-1098.

Larsen, L.M., Pedersen, A.K., 2009. Petrology of the Paleocene Picrites and Flood Basalts on Disko and Nuussuaq, West Greenland. Journal of Petrology 50, 1667-1711.

Larsen L.M., Pedersen, A.K., Tegner, C., Duncan, R.A., Hald, N., Larsen, J.G., 2015. Age of Tertiary volcanic rocks on the West Greenland continental margin: volcanic evolution and event correlation to other parts of the North Atlantic Igneous Province. Geol. Mag. 153, 487-511.

Larsen, J.G., Pulvertaft, T.C.R. 2000. The structure of the Cretaceous-Palaeogene sedimentary-volcanic area of Svartenhuk Halvø, central West Greenland. Geology of Greenland Survey Bulletin, 188, 1-40.

Larsen, H.C., Saunders, A.D., 1998. Tectonism and volcanism at the southeast Greenland rifted margin: a record of plume impact and later continental rupture. Proc. Ocean Drill. Program Sci. Results 152, 503-533.

Le Bas, M., Le Maitre, R., Streckeisen, A., Zanettin, B., 1986. A chemical classification of volcanic rocks based on the total alkali silica diagram. Journal of Petrology 27, 745-750. 
Le Breton, E., Cobbold, P.R., Dauteuil, O., Lewis, G., 2012. Variations in amount and direction of seafloor spreading along the northeast Atlantic Ocean and resulting deformation of the continental margin of northwest Europe. Tectonics 31, TC5006.

Lee, C.-T.A., Luffi, P., Plank, T., Dalton, H., Leeman, W.P., 2009. Constraints on the depths and temperatures of basaltic magma generation on Earth and other terrestrial planets using new thermobarometers for mafic magmas. Earth Planet. Sci. Lett. 279, 20-33.

Li, Z.X.A., Lee, C.-T.A., 2006. Geochemical investigation of serpentinized oceanic lithospheric mantle in the Feather River Ophiolite, California: Implications for the recycling rate of water by subduction. Chemical Geology 235, 161-185.

Macdonald, G.A., Katsura, T., 1964. Chemical composition of Hawaii lavas. Journal of Petrology 5, 82-133.

Maclennan, J., 2008. Lead isotope variability in olivine-hosted melt inclusions from Iceland Geochim. Cosmochim. Acta 72 4159-4176.

McDonough, W.F., Sun, S.S., 1995. The composition of the Earth. Chem. Geol. 120, 223-253.

McKenzie, D., O’Nions, R.K., 1991. Partial melt distribution from inversion of Rare Earth Element concentrations. Journal of Petrology 32, 5, 1021-1091.

Meade, F.C., Troll, V.R., Ellam, R.M., Freda, C., Font, L., Donaldson, C.H., Klonowska, I., 2014. Bimodal magmatism produced by progressively inhibited crustal assimilation. Nat. Commun. 5, 4199, DOI: 10.1038/ncomms5199.

Meyer, R., Van Wijk, J., Gernigon, L., 2007. The North Atlantic Igneous Province: a review of models for its formation. Geol. Soc. Amer., Special Paper 430, 525552.

Mougel, B., Agranier, A., Hemond, C., Gente, P., 2014. A highly unradiogenic lead isotopic signature revealed by volcanic rocks from the East Pacific Rise. Nat. Commun. 5, 4474. https://doi.org/10.1038/ncomms5474

Moynier, F., Agranier, A., Hezel, D.C., Bouvier, A., 2010. Sr stable isotope composition of Earth, the Moon, Mars, Vesta and meteorites. Earth Planet. Sci. Lett. 300, 359-366.

Oakey, G.N., Chalmers, J.A., 2012. A new model for the Paleogene motion of Greenland relative to North America: Plate reconstructions of the Davis Strait and Nares Strait regions between Canada and Greenland. J. Geoph. Res. Solid Earth 117, B10401.

Ogg, J.G., 2012. Geomagnetic Time Scale. In: Gradstein, F.M., Ogg, J.G., Schmitz, M., Ogg, G. (eds), The Geologic Time Scale 2012. Elsevier, Amsterdam, 85-113.

O'Neill, H.S.C., 1981. The transition between spinel lherzolite and garnet lherzolite, and its use as a geobarometer. Contrib. Mineral. Petrol. 77: 185-194.

Peate, D.W., Baker, J.A., Jakobsson, S.P., Waight, T.E., Kent, A.J.R., Grassineau, N.V., Skovgaard, A.C., 2009. Historic magmatism on the Reykjanes Peninsula, Iceland: a snap-shot of melt generation at a ridge segment. Contrib. Mineral. Petrol. 157, 3, 359-382.

Peate, D.W., Breddam, K., Baker, J.A., Kurtz, M., Barker, A.K., Prestvik, T., Grassineau, N., Skovgaard, A.C., 2010. Compositional characteristics and spatial distribution of enriched Icelandic mantle components. Journal of Petrology 51, 7, 1447-1475.

Peate, D.W., Stecher, O., 2003. Pb isotope evidence for contributions from different Iceland mantle components to Palaeogene East Greenland flood basalts. Lithos $67,1-2,39-52$. 
Pedersen, G.K., Larsen, L.M., Pedersen, A.K., Hjortkjaer, B.F., 1998. The synvolcanic Naajaat lake, Paleocene of West Greenland. Palaeogeogr. Palaeoclimatol. Palaeoecol. 140, 271-287.

Pedersen, A.K., Larsen, L.M., Riisager, P., Dueholm, K.S., 2002. Rates of volcanic deposition, facies changes and movements in a dynamic basin: the Nuussuaq Basin, West Greenland, around the C27n-C26r transition. In: Jolley, D. W. and Bell, B.R. (eds) The North Atlantic Igneous Province: Stratigraphy, Tectonic, Volcanic and Magmatic Processes. Geological Society, London, Special Publications 197, 157-181.

Péron, S., Moreira, M., Agranier, A., 2018. Origin of Light Noble Gases (He, Ne, and Ar) on Earth: A Review. Geochem. Geophys. Geosystems 19, 4, 979-996, http://DOI: 10.1002/2017GC007388.

Petersen, K.D., Schiffer, C., Nagel, T., 2018. LIP formation and protracted lower mantle upwelling induced by rifting and delamination. Scientific Reports 8, 16578, DOI:10.1038/s41598-018-34194-0.

Pik, R., Deniel, C., Coulon, C., Yirgu, G., Hofmann, C., Dereje, A., 1998. The Northwestern Ethiopian Plateau flood basalts : Classification and spatial distribution of magma types. J. Volcanol. Geotherm. Res. 91-111.

Planke, S., Symonds, P.A., Avelstad, E., Skogseid, J., 2000. Seismic volcanostratigraphy of large-volume basaltic extrusive complexes on rifted margins. J. Geophys. Res. 105, 19333-19351.

Riisager, P., Abrahamsen, N., 1999. Magnetostratigraphy of Palaeocene basalts from the Vaigat Formation of West Greenland. Geophysical Journal International 137, 774-782.

Riisager, J., Riisager, P., Pedersen, A.K., 2003. Paleomagnetism of large igneous provinces:Case-study from West Greenland, North Atlantic igneous province, Earth Planet. Sci. Lett. 214, 409-425.

Robinson, J.A.C., Wood, B.J., 1998. The depth of the spinel to garnet transition at the peridotite solidus. Earth Planet. Sci. Lett. 164, 277-284.

Roest W. R., Srivastava, S.P., 1989. Sea-floor spreading in the labrador sea - a new reconstruction. Geology 17, 11, 1000-1003.

Rudnick, R., Fountain, D., 1995. Nature and composition of the continental crust, a lower crustal perspective. Rev. Geophys. 33, 267-309.

Rudnick, R., Gao, S., 2003. Composition of the continental crust, in: The Crust. Elsevier, Oxford, pp. 1-64.

Ryabchikov, I., Brooks, C.K., Kogarko, L.N., Nielsen, T., Solovova, I.P., Turkov, V., 1998. Tertiary picrites from Greenland: modelling sources and petrogenesis from melt inclusioncompositions. Mineral. Mag. 62A, 3, 1306-1307

Saunders, A.D., Fitton, J.G., Kerr, A.C., Norry, M.J., Kent, R.W., 1997. The North Atlantic igneous province. In: Mahoney, J.J., Coffin, M.F. (Eds.), Large Igneous Provinces: Continental, Oceanic, and Planetary Flood Volcanism. AGU Geophysical Monograph, Washington, 45-93.

Saunders A.D., Jones, S.M., Morgan, L.A., 2007. Regional uplift associated with continental large igneous provinces: The roles of mantle plumes and the lithosphere. Chem. Geol. 241, 3-4, 282-318.

Self, S., Thordarson, T., Keszthelyi, L., 1997. Emplacement of continental flood basalt lava flows. In: Mahoney, J.J., Coffin, M.F. (Eds.), Large Igneous Provinces: Continental, Oceanic, and Planetary Flood Volcanism. AGU Geophysical Monograph, Washington, 381-410. 
Shellnutt, J.G., Jahn, B.-M., 2011. Origin of Late Permian Emeishan basaltic rocks from the Panxi region (SW China): Implications for the Ti-classification and spatial-compositional distribution of the Emeishan flood basalts. J. Volcanol. Geotherm. Res. 199, 85-95.

Simon, K., Huismans, R.S., Beaumont, C., 2009. Dynamical modelling of lithospheric extension and small-scale convection: Implications for magmatism during the formation of volcanic rifted margins. Geophys. J. Int. 176, 1, 327-350.

Sims, K.W.W., Maclennan, J., Blichert-Toft, J., Mervine, E.M., Blusztajn, J., Gronvold, K., 2013. Short length scale mantle heterogeneity beneath Iceland probed by glacial modulation of melting. Earth Planet. Sci. Lett. 379, 146-157.

Skaarup, N., Jackson, H.R., Oakey, G., 2006. Margin segmentation of Baffin Bay/Davis Strait, eastern Canada, based on seismic reflection and potential field data. Marine Petroleum Geology 23, 127-144.

Stica, J.M., Zalan, P.V., Ferrari, A.L., The evolution of rifting on the volcanic margin of the Pelotas Basin and the contextualization of the Parana-Etendeka LIP in the separation of Gondwana in the South Atlantic. Marine Petroleum Geology 50, $1-21$.

Storey, M., Duncan, R.A., Pedersen, A.K., Larsen, L.M., Larsen, H.C., 1998. ${ }^{40} \mathrm{Ar} /{ }^{39} \mathrm{Ar}$ geochronology of the West Greenland Tertiary volcanic province. Earth and Planetary Science Letters 160, 569-586.

Stracke, A., Zindler, A., Salters, V.J.M., McKenzie, D., Blichert-Toft, J., Albarede, F., Gronvold, K., 2003. Theistareykir revisited. Geochem. Geophys. Geosystems 4, 8507. https://doi.org/10.1029/2001GC000201

Suckro, S.K., Gohl, K., Funck, T., Heyde, I., Ehrhardt, A., Schreckenberger, B., Gerlings, J., Damm, V., Jokat, W., 2012. The crustal structure of southern Baffin Bay: implications from a seismic refraction experiment. Geophys. J. International 190, 1, 37-58.

Tanaka, T., Togashi, S., Kamioka, H., Amakawa, H., Kagami, H., Hamamoto, T., Yuhara, M., Orihashi, Y., Yoneda, S., Shimizu, H., Kunimaru, T., Takahashi, K., Yanagi, T., Nakano, T., Fujimaki, H., Shinjo, R., Asahara, Y., Tanimizu, M., Dragusanu, C., 2000. JNdi-1: a neodymium isotopic reference in consistency with LaJolla neodymium. Chem. Geol. 168, 279-281.

Tang, M., Lee, C.T.A., Chen, K., Erdman, M., Costin, G., Jiang, H.H., 2019. Nb/Ta systematics in arc magma differentiation and the role of arclogites in continent formation. Nat. Commun., 10, 235, DOI: 10.1038/s41467-018-08198-3.

Tegner, C., Lesher, C.E., Larsen, L.M., Watt, W.S., 1998. Evidence from the rareearth-element record of mantle melting for cooling of the tertiary Iceland plume. Nature 395, 6702, 591-594.

Thirlwall, M.F., Gee, M.A.M., Taylor, R.N., Murton, B.J., 2004. Mantle components in Iceland and adjacent ridges investigated using double-spike $\mathrm{Pb}$ isotope ratios. Geochim. Cosmochim. Acta 68, 361-386.

Thirlwall, M.F., Upton, B.G.J., Jenkins, C., 1993. Interaction between continental lithosphere and the Iceland Plume $-\mathrm{Sr}, \mathrm{Nd}, \mathrm{Pb}$, isotope geochemistry of Tertiary basalts, NE Greenland. Journal of Petrology 35, 3, 839-879.

Todt, W., Cliff, R.A., Hansen, A., Hofmann, A., 1996. Evaluation of a ${ }^{202} \mathrm{~Pb}-{ }^{205} \mathrm{~Pb}$ double spike for high-precision isotope analysis. In: Earth Processes: Reading the Isotopic Code (Eds: A. Basu, S.R. Hart).Am.Geophys. Union Geophysical Monograph 95, 429-437. 
Torsvik, T.H., Van der Voo, R., Meert, J.G., Mosar, J., Walderhaug, H.J., 2001. Reconstructions of the continents around the North Atlantic at about the 60th parallel. Earth Planet. Sci. Lett. 187, 55-69.

White, W., McKenzie, D., 1989. Magmatism at rift zones-the generation of volcanic continental margins and flood basalts. Journal of Geophys. Res.- Solid Earth 94, 7685-7729.

Willbold, M., Hegner, E., Stracke, A., Rocholl, A., 2009. Continental geochemical signatures in dacites from Iceland and implications for models of early Archaean crust formation. Earth Planet. Sci. Lett. 279, 1-2, 44-52.

Wilson, S.A., 1997. The collection, preparation, and testing of USGS reference material BCR-2, Columbia River, Basalt: U.S. Geological Survey Open-File Report 98.

\section{Figure captions}

Figure 1: Simplified structural map of Greenland and Northern Atlantic Igneous

Province, modified after Chauvet et al (accepted). The studied area (red square) is located on the western volcanic margin of Greenland.

Figure 2: The 45 sampling sites (numbers) located on the simplified geological map of Svartenhuk Peninsula (West Greenland), modified after Chauvet et al. (accepted). Locations of cross sections AA', BB' and CC' are shown on the map.

Figure 3: Major element compositions of samples from units V1 (purple triangles), V2 (beige circles), V3 (blue hexagons) and V4 (yellow triangles). A: Total alkali Silica plot (Le Bas et al., 1986). The thick black line (Macdonald and Katsura, 1964) separates the fileds of subalkaline basaltic series (below) from alkali basaltic series (above).

B: $\mathrm{CaO}$ vs $\mathrm{SIO}_{2}$ and $\mathrm{Ni}$ vs $\mathrm{SiO}_{2}$ plots. Compositions range from basaltic to trachytic (the latter in V4 unit only) following olivine and plagioclase + pyroxene fractionation trends. Dashed line identifies primitive Ni concentrations (higher than $400 \mathrm{ppm}$ ) and dotted line denotes samples with $\mathrm{MgO}=12 \mathrm{wt} \%$, consistent with olivine phenocryst compositions $(\mathrm{Mg} \#=0.83$, supplementary table 1$)$.

Figure 4: Multielement patterns of Svartenhuk samples. A: Rare earth element (REE) patterns normalized to CI Chondrite (McDonough and Sun, 1995) for samples from units V1 (pink), V2 (beige), V3 (blue) and V4 (yellow). Samples from V1 and V4 have comparable REE patterns with significant light REE enrichments compared with 
heavy REE, typical of alkali and transitional basaltic lavas. Samples from units V2 and V3 have more diverse signatures ranging from alkali to tholeiitic (LREE depleted) patterns. B: Multielement plot normalized to Primitive mantle (McDonough and Sun, 1995) compiling all samples (V1=purple lines, V2= beige lines, V3= blue lines, V4= yellow lines) and the median compositions of each group (V1= purple triangles, V2= beige circles, V3= blue hexagons, V4= yellow triangles).

Figure 5: Plot of $\mathrm{SiO}_{2}$ vs $\mathrm{Pb}$ concentrations and $\mathrm{Nb} / \mathrm{La}$ ratios. Continental crust contamination typically generates $\mathrm{SiO}_{2}$ and $\mathrm{Pb}$ enrichments (Rudnick and Fountain, 1995) associated with $\mathrm{Nb}$ depletions (Tang et al, 2019 and references therein) illustrated here by low $\mathrm{Nb} / \mathrm{La}$ ratios. Crustal contamination trends (black arrows) can be identified within samples from units V1 and V2 only. for color codes) are plotted together with basalts from the North Atlantic ridge : blue crosses (Agranier et al., 2005; Blichert-Toft et al., 2005), Iceland : gray squares: (Breddam, 2002; Chauvel and Hémond, 2000; Hanan and Schilling, 1997; Hanan et al., 2000, Kitawaga et al., 2008; Kokfelt et al., 2009; Kuritani et al., 2011; Peate et al., 2010, 2009; Sims et al., 2013; Stracke et al., 2003; Thirlwall et al., 2004; Willbold et al., 2009) and East Greenland: orange crosses (Barker et al., 2006). Samples from this study plot between three end-members materialized by letters Sk1, Sk2 and Sk3. The Sk1-Sk2 trend can be accounted for by crustal contamination (Sk1 features radiogenic $\mathrm{Sr}$, and unradiogenic $\mathrm{Pb}, \mathrm{Hf}$ and $\mathrm{Nd}$ ); while Sk2-Sk3 largely overlaps with mantle like signatures (Kitawaga et al. 2008) including North Mid-Atlantic Ridge and Iceland

1110 basalts. Its trend in all diagrams appears to point toward the common component $\mathrm{C}$ of 1111 Hanan and Graham (1996).

Figure 7: Pb isotopic data. Samples from this study are represented together with basalts 1114 from Iceland (gray squares, see figure 6 for references) and East Greenland (Barker et 1115 al., 2006) (orange crosses). The Iceland plume inner components: D, E-1 and E-2 1116 (Kitawaga et al., 2008; Thirlwall et al., 2004) are also located in this diagram. Apart 1117 from continental crust trend (segment Sk1-Sk2), all samples plot within in a triangle 1118 delineated by D, E-1 and E-2. 
1120 Figure 8: Plots of ${ }^{206} \mathrm{~Pb} /{ }^{204} \mathrm{~Pb}, \mathrm{La} / \mathrm{Sm}, \mathrm{Sm} / \mathrm{Yb}$ against $\mathrm{La} / \mathrm{Yb}$. $\mathrm{Pb}$ isotopes (upper

1121 diagram) evidence crustal contamination for some V1 and V2 lavas and mantle-like

1122 compositions for most of the sample set. $\mathrm{La} / \mathrm{Sm}$ as well as $\mathrm{Sm} / \mathrm{Yb}$ provide insights

1123 about melting rates. On the $\mathrm{Sm} / \mathrm{Yb}$ plot are reported for comparison the results of

1124 simple batch melting models considering garnet bearing (red line) and spinel bearing

1125 (green line) depleted lherzolite as proposed for Iceland by Gurenko and Chaussidon

1126 (1995), partition coefficients by McKenzie and O’Nions (1991) and mineral

1127 proportions by Thirlwall et al. (1993). Numbers from 0.02 to 0.1 denote F values. The

1128 higher $\mathrm{Sm} / \mathrm{Yb}$ values observed for most of V1 and V4 lavas suggest a stronger

1129 involvement of garnet in their sources.

1131 Figure 9: Plots of ${ }^{206} \mathrm{~Pb} /{ }^{204} \mathrm{~Pb}, \mathrm{La} / \mathrm{Sm}$ and $\mathrm{Sm} / \mathrm{Yb}$ against $\Delta \mathrm{Nb}=1.74+\log (\mathrm{Nb} / \mathrm{Y})-$

$11321.92 \log (\mathrm{Zr} / \mathrm{Y})$ (Fitton et al., 1997). $\Delta \mathrm{Nb}$ is considered as a bench marker of Iceland

1133 plume affinity. Only samples from units V2 and V3 display negative $\Delta \mathrm{Nb}$, indicative

1134 of the contribution of "normal" upper mantle devoid of plume related enriched

1135 component. The thick black arrows illustrate the temporal evolution of Icelandic

1136 material contribution from V1 to V4.

1137

1138

1139

1140

1141

1142

1143

1144

1145

1146

1147

1148

1149

1150

1151 Figure 11: Tentative tectonic sketches depicting Svartenhuk magmatic evolution in 1152 relation with the evolution of South Baffin Bay during the Paleogene, at the times of $1153 \mathrm{~V} 1, \mathrm{~V} 2-\mathrm{V} 3$ and V4 emplacements. Sk1, Sk2 and Sk3 refer to crustal and mantle

Figure 10: Sketch summarizing the four main stages of Svartenhuk volcanism deduced from geochemical and petrologic constraints. Sk1, Sk2 and Sk3 represent the three geochemical reservoirs defined in figures 6 and 7. The tectonic evolution of the lithosphere (crustal thinning) is more precisely depicted in figure 11. During V1 stage, decompression melting affects Iceland plume-like material ascending through the asthenosphere below an already thinned lithosphere. During V2, the ongoing crustal thinning leads to an uprise of the isotherms and therefore to the upward propagation of partial melting and to its increase. During the emplacement of these two first units, geochemical signatures (benchmarked by $\mathrm{Pb}$ isotopes on the bottom diagram) can be accounted for by the simple binary mixture of components Sk1 and Sk2. During V3, the melting has propagated within Sk3 reservoir. Finally, during V4, the melting deepens again and is once more mostly restricted to reservoir Sk2. See text for details. 
1154 reservoirs discussed in the text and shown in figure 10. Convection geometry is purely 1155 conceptual, and based on small scale convection models (Petersen et al., 2018; Simon et 1156 al., 2009). In the V1 sketch (top left), the occurrence of Cretaceous sediments, shown in

1157 light green suggests that crustal thinning started during the Cretaceous. The melting 1158 zones are indicated with coloured dots. Red boxes show the location of our field and 1159 petrologic investigations. The shaded areas on the left of some diagrams underline the 1160 speculative character of these interpretations when extrapolated to areas located away 1161 from our study area.

1163 Table 1: Sample locations. K/Ar and Ar/Ar ages are from Chauvet et al (accepted)

1164 Table 2: Major element data (oxide wt\%, total iron as $\mathrm{Fe}_{2} \mathrm{O}_{3}$, LOI: Loss On Ignition). 1165 Analytical methods are presented in the text.

1166 Table 3: Trace element data (ppm). Analytical methods are presented in the text.

1167 Table 4: $\mathrm{Pb}, \mathrm{Hf}, \mathrm{Sr}$ and $\mathrm{Nd}$ isotopic data. Analytical methods are presented in the text.

1169 Supplementary Table 1: ICP-MS repeated trace element analyses for standards BHVO2, $1170 \quad$ BCR-2 and BIR1.

1171 Supplementary Table 2: MC-ICP-MS repeated $\mathrm{Nd}$, Hf and $\mathrm{Pb}$ isotope analyses of 1172 standards JNDi-1, JMC475 and NIST981, respectively.

1173 Supplementary Table 3: Replicated analyses of $\mathrm{Pb}, \mathrm{Hf}, \mathrm{Nd}$ and $\mathrm{Sr}$ isotopic compositions of sample S39E1.

1175 Supplementary Table 4: Olivine compositions obtained on Cameca SX100 electron

1176 microprobe at Service Commun "Microsonde Ouest" (Plouzané), at $15 \mathrm{kV}$

1177 accelerating voltage with a probe current of $12 \mathrm{nA}$. 


\section{Figure 1}

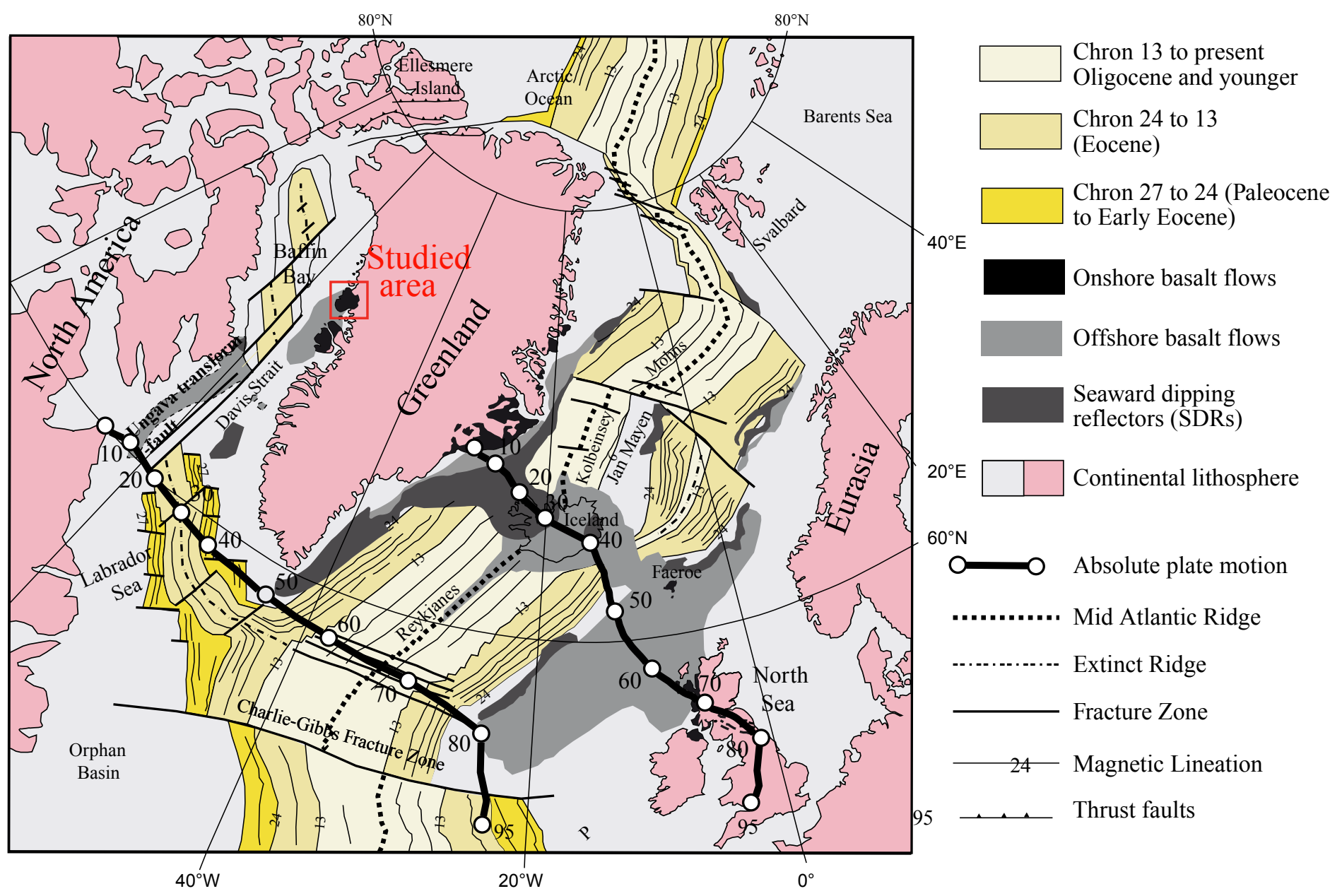




\section{Figure 2}

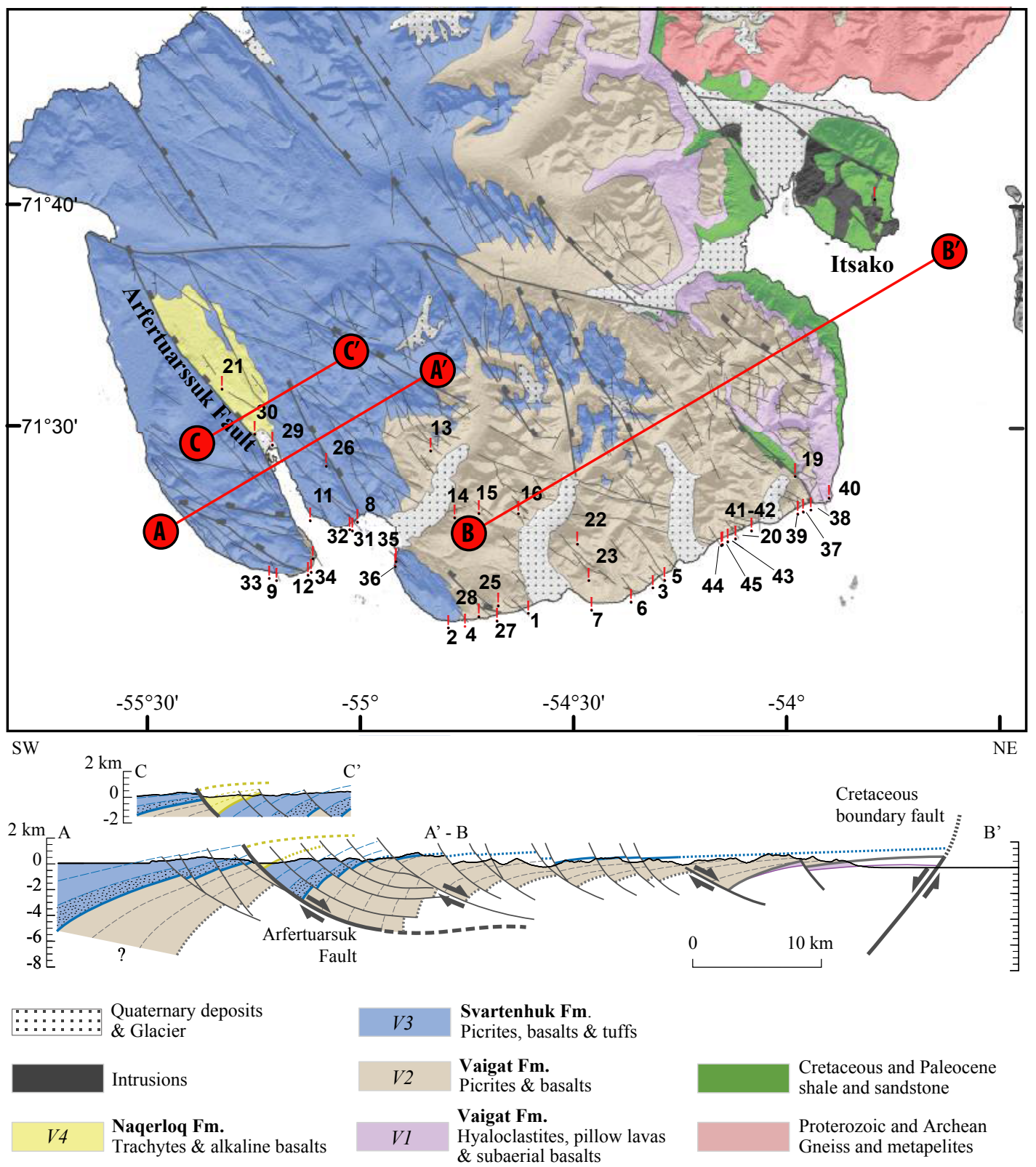




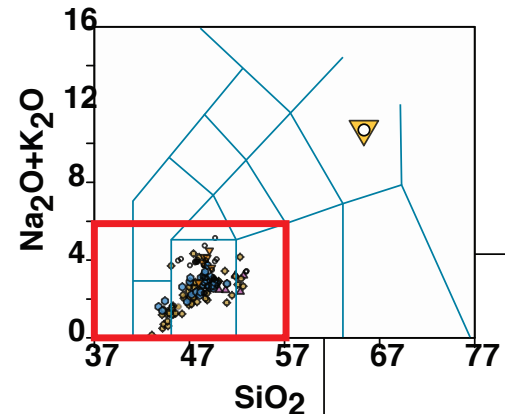

 basanite

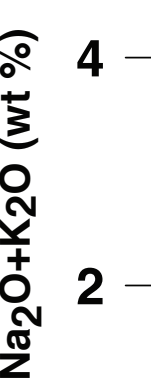

$$
0
$$

0

37

40

45

45

50

55

$\mathrm{SiO}_{2}$ (wt \%)

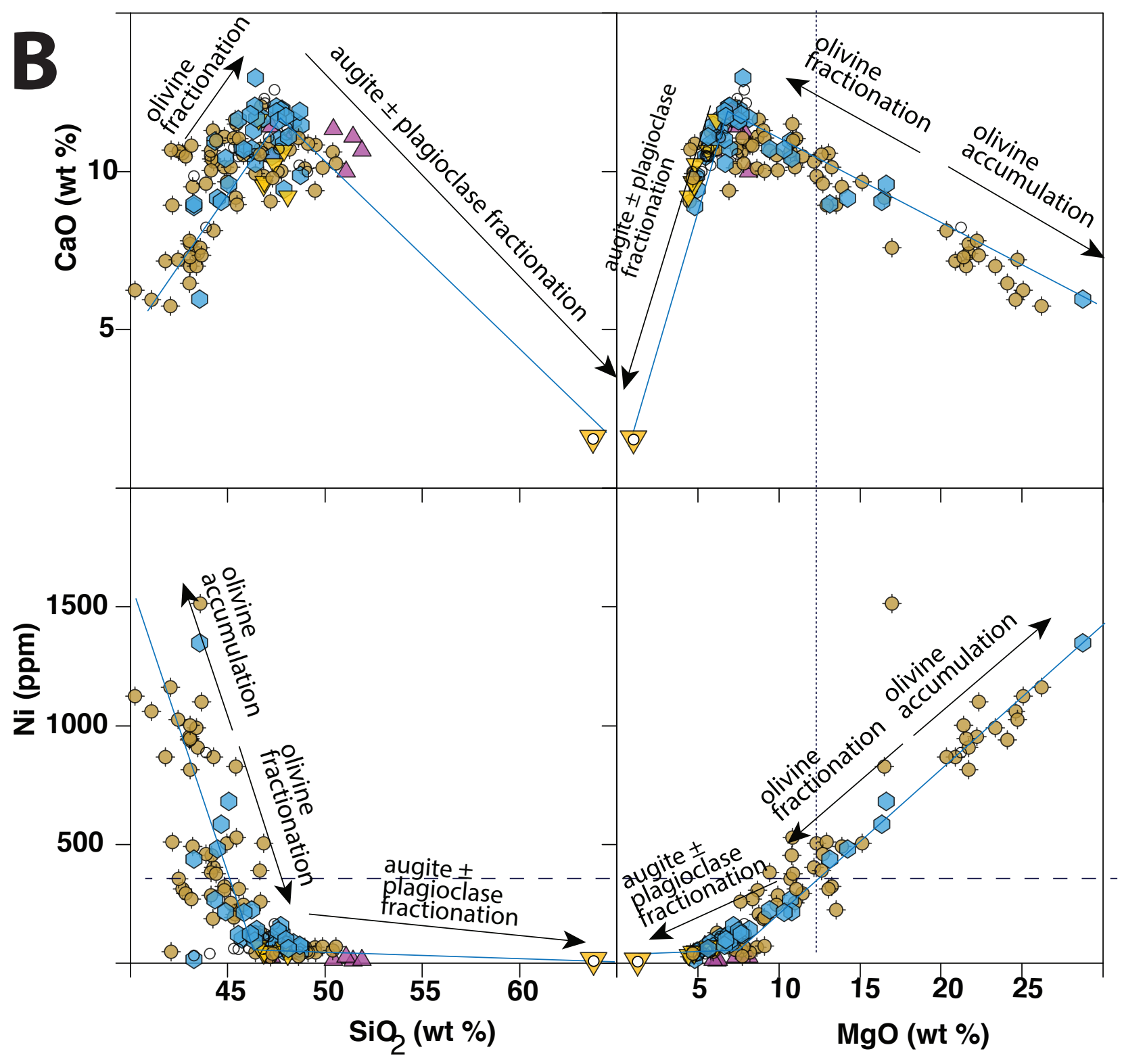




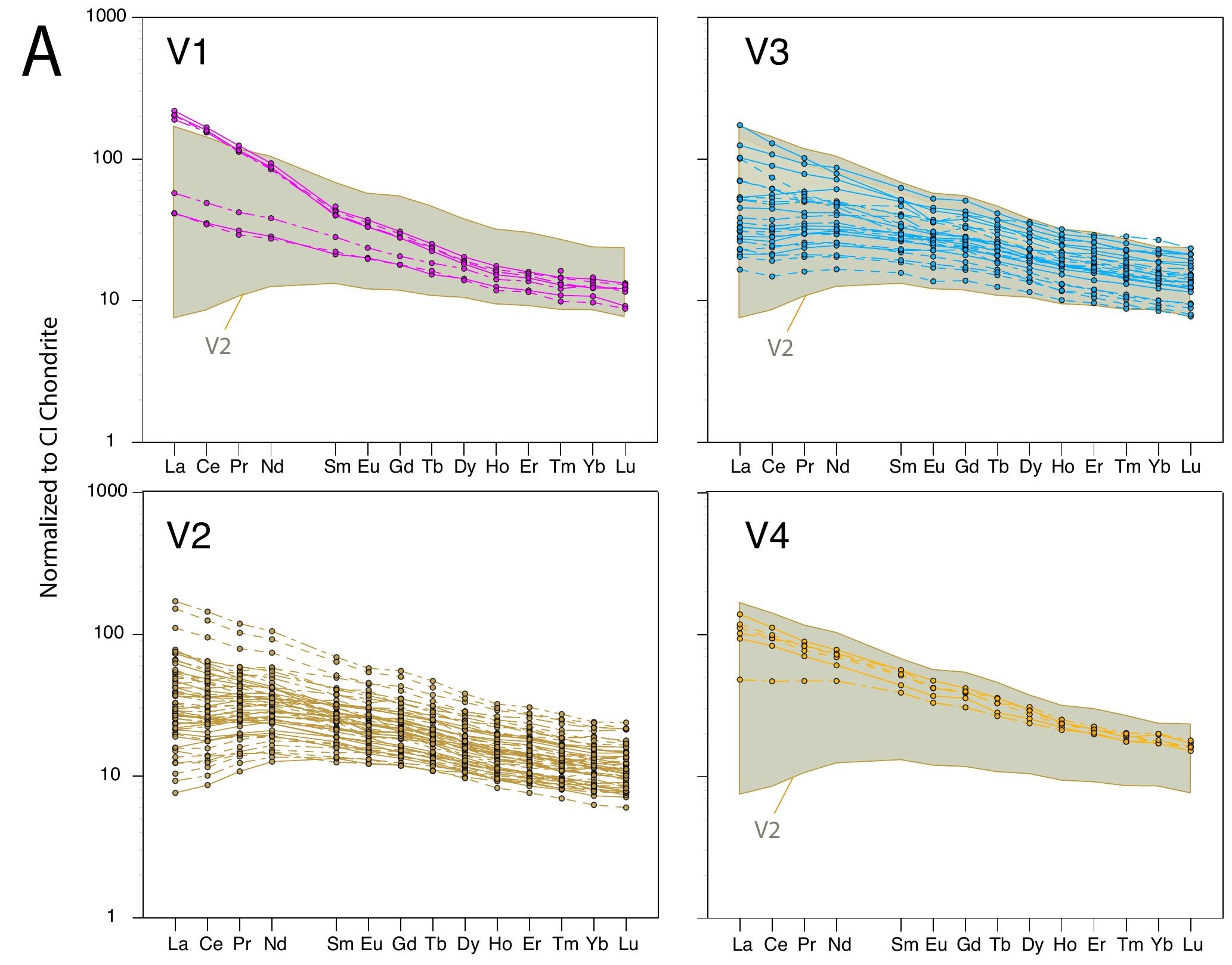

B

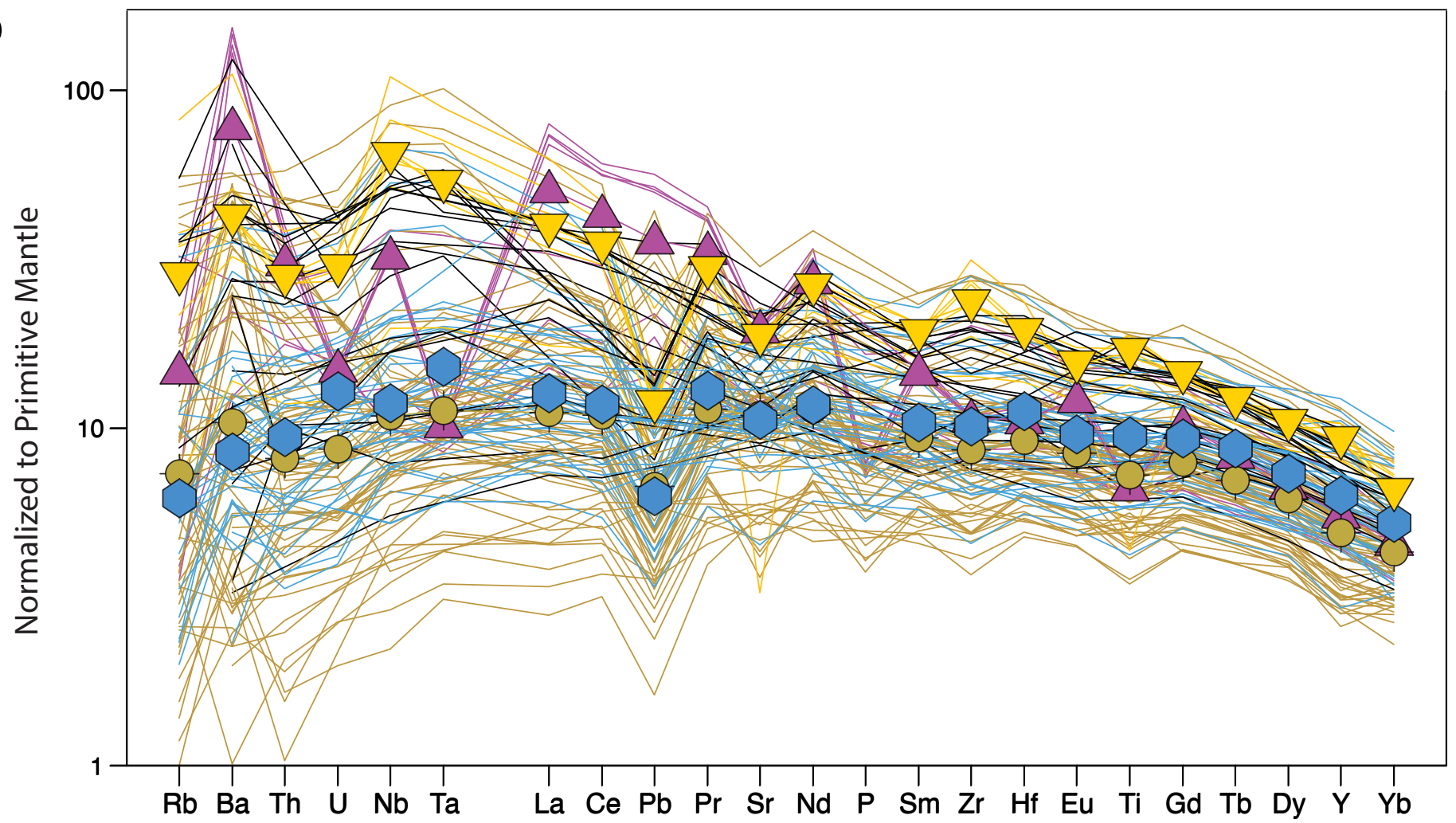




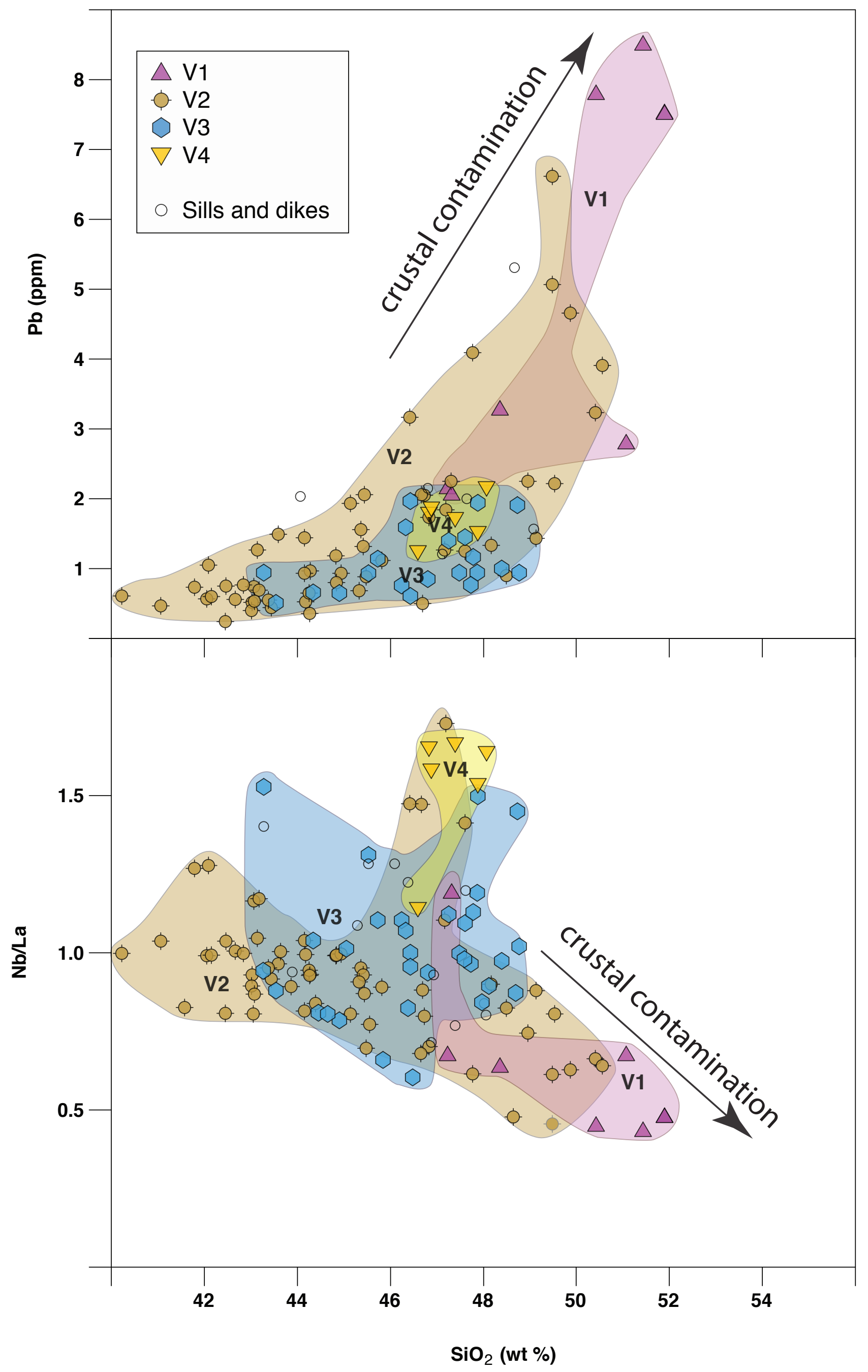





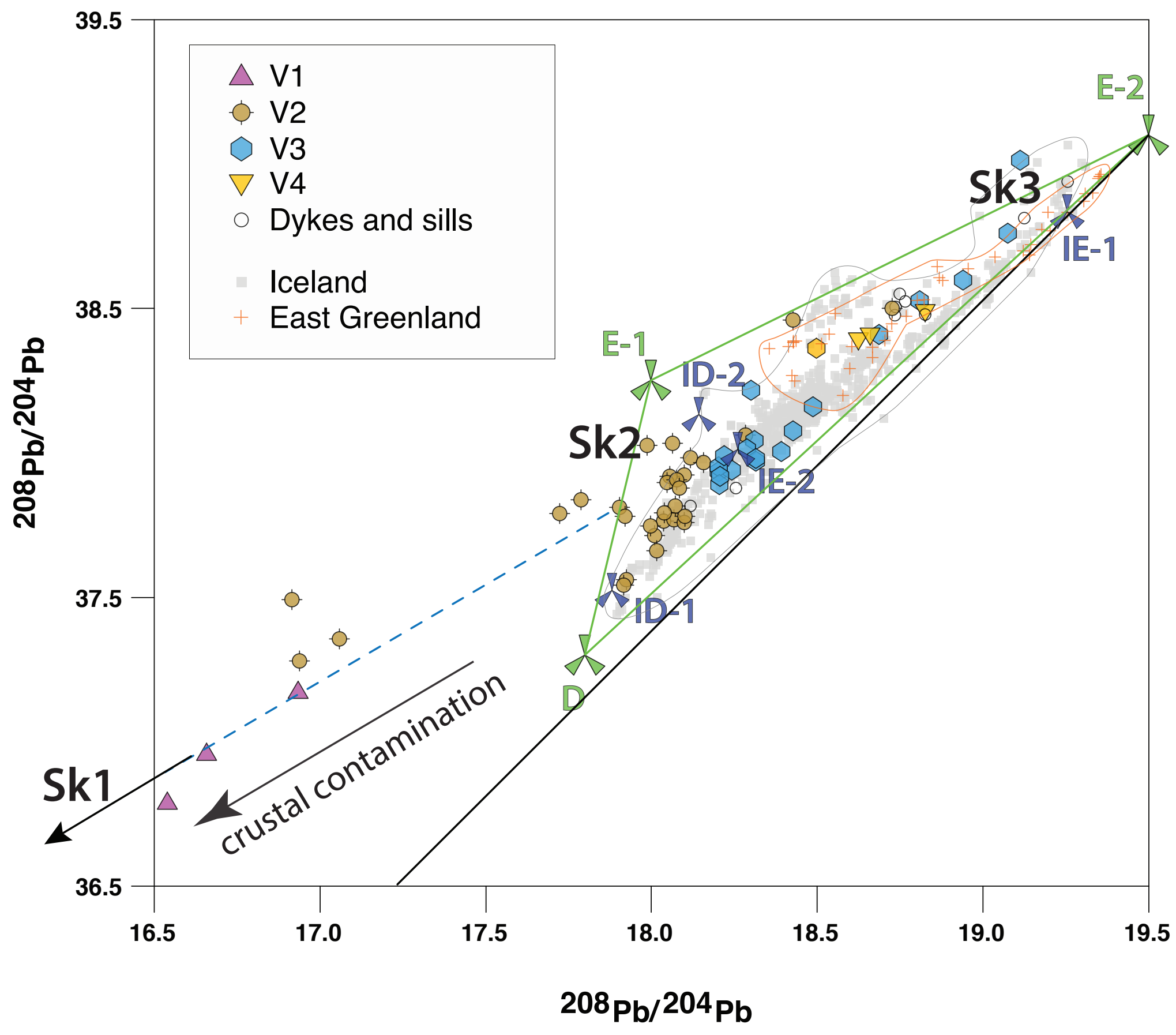




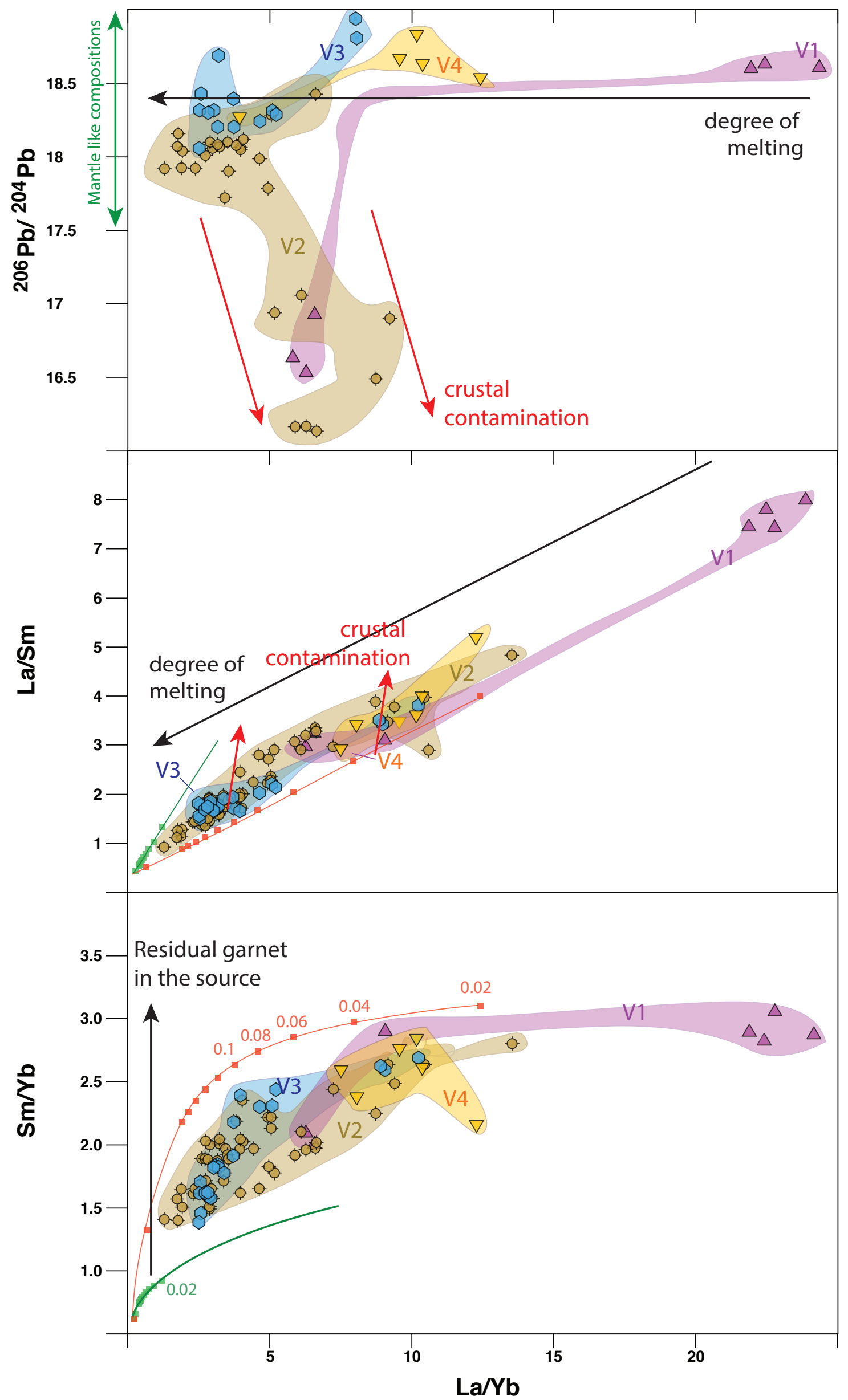




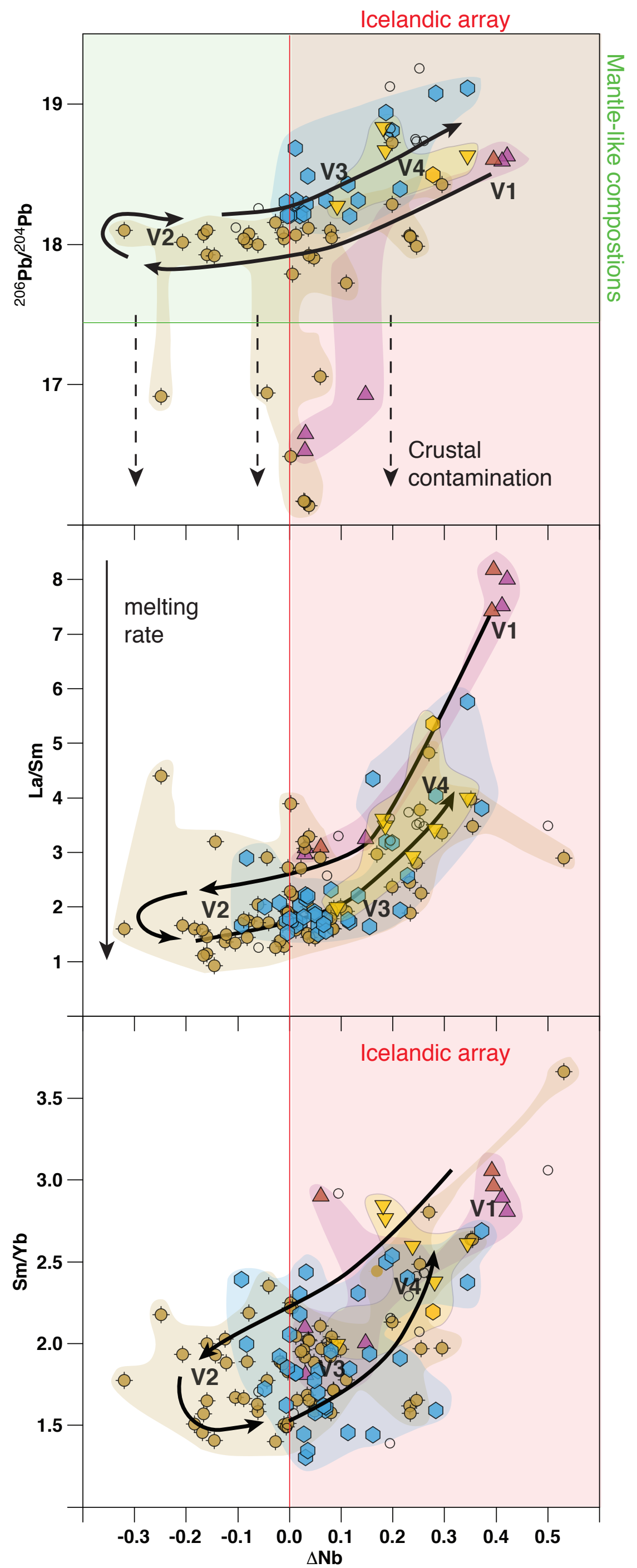



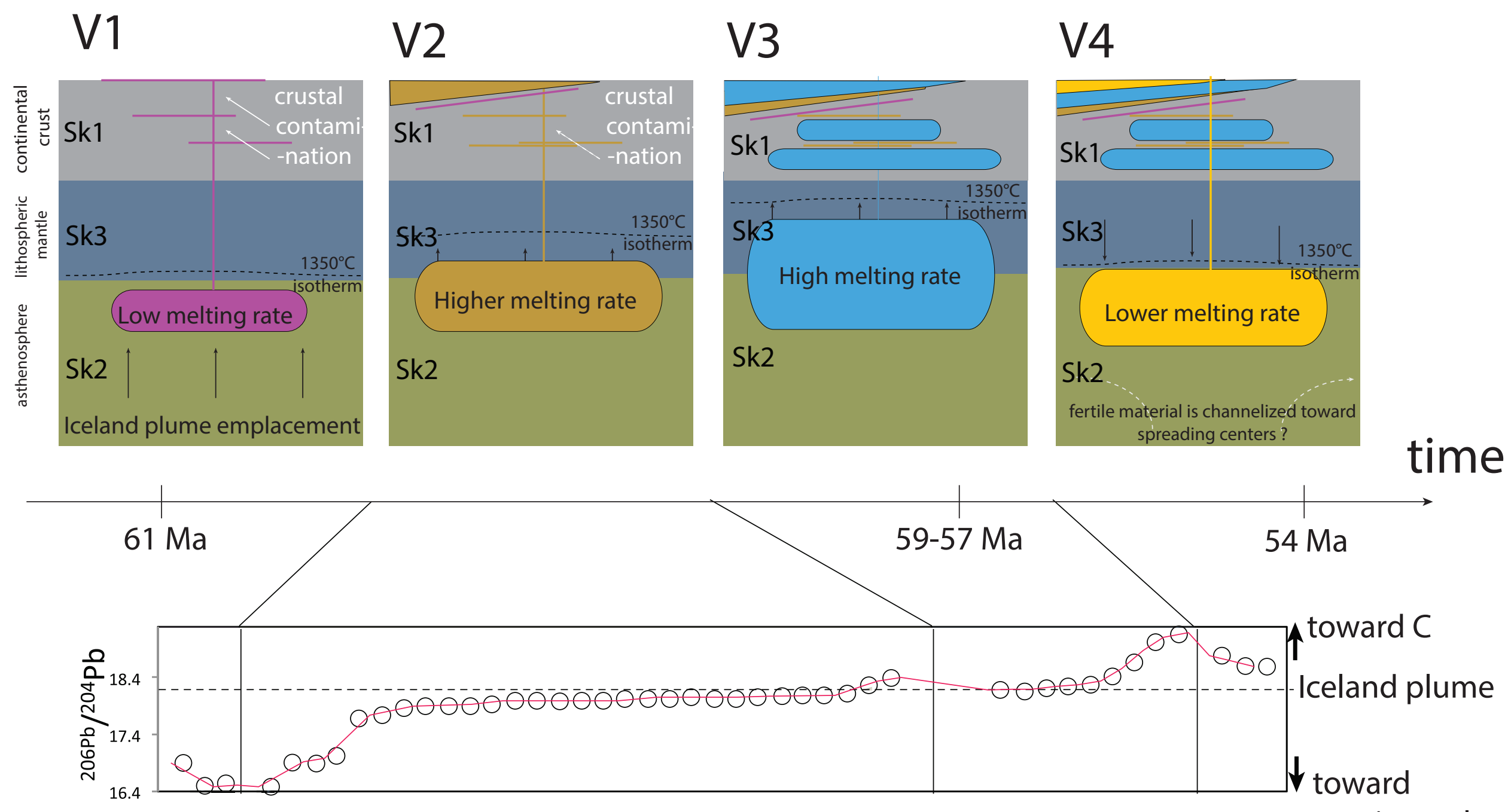

continental crust 

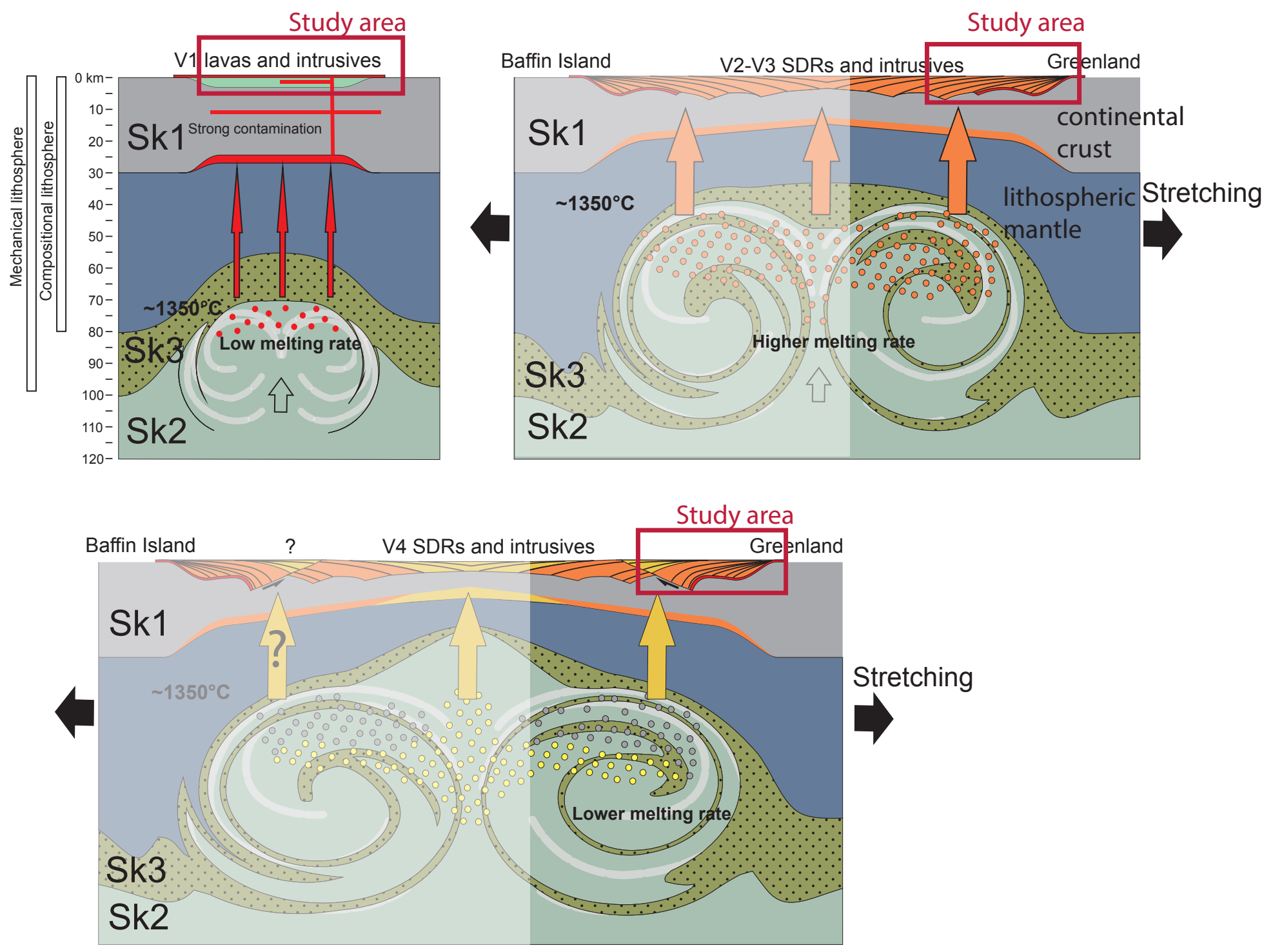


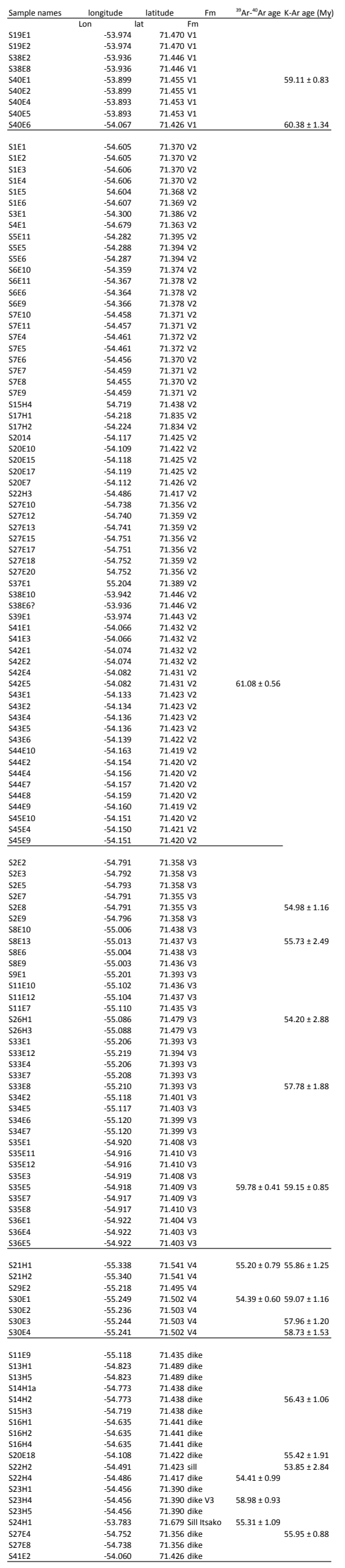




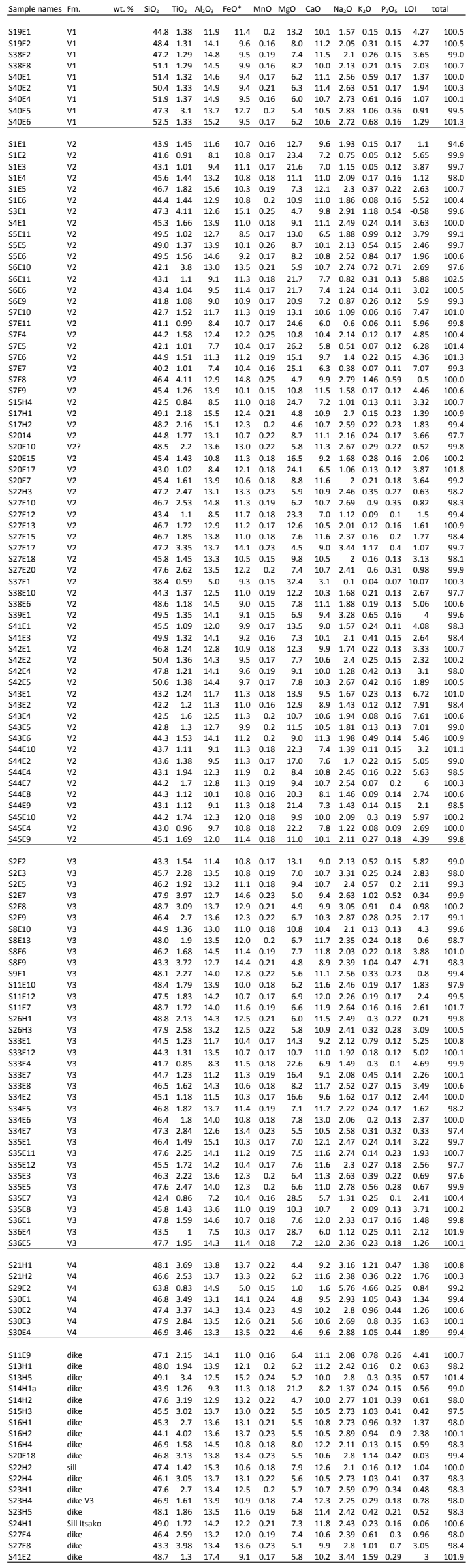




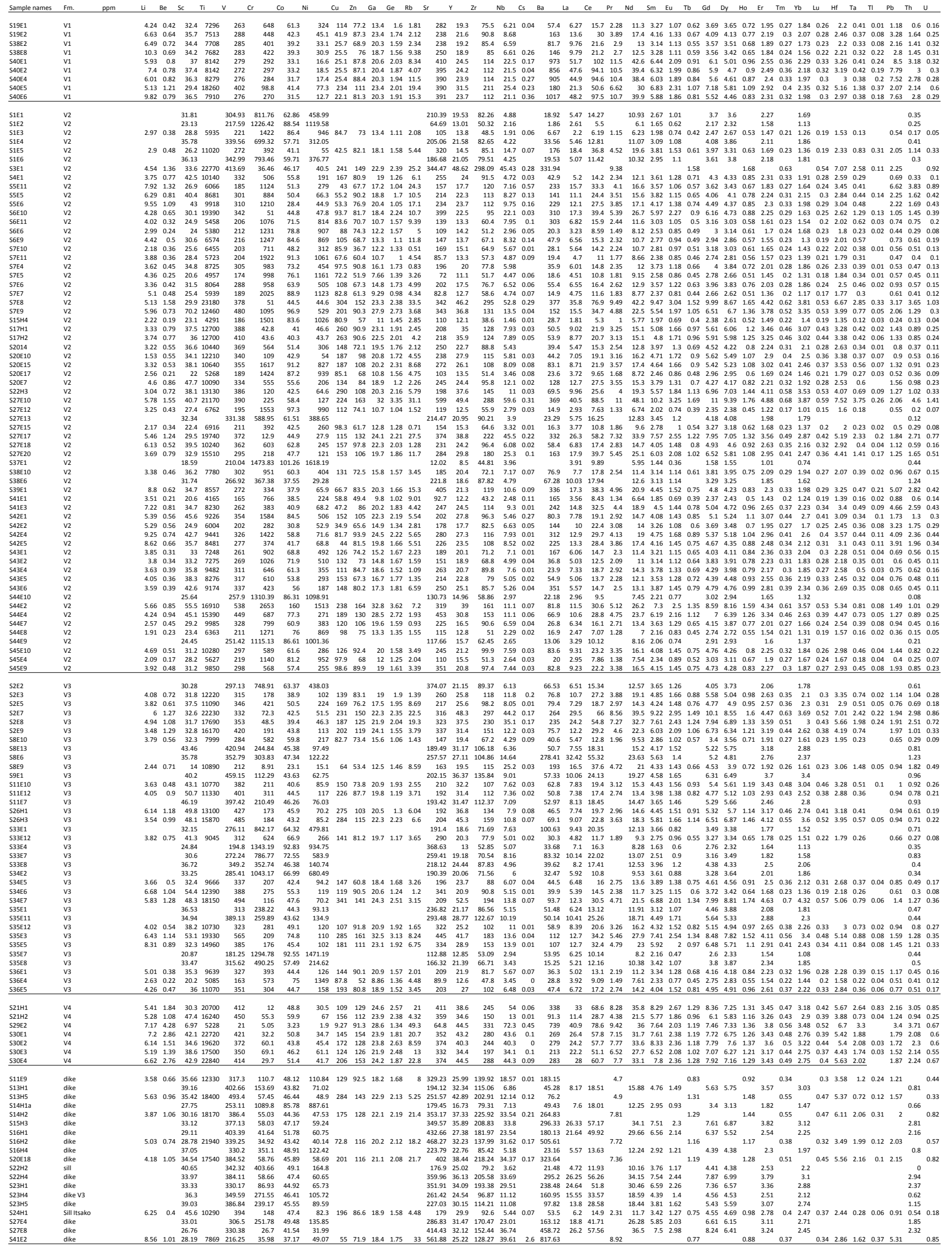




\begin{tabular}{|c|c|c|c|c|c|c|c|c|c|c|c|}
\hline Sample names & $\mathrm{Fm}$. & ${ }^{208} \mathrm{~Pb} /{ }^{204} \mathrm{~Pb}$ & ${ }^{207} \mathrm{~Pb} /{ }^{204} \mathrm{~Pb}$ & ${ }^{206} \mathrm{~Pb} /{ }^{204} \mathrm{~Pb}$ & ${ }^{176} \mathrm{Hf} /{ }^{177} \mathrm{Hf}$ & $2 \sigma$ & $\varepsilon_{\mathrm{Hf}}$ & ${ }^{143} \mathrm{Nd} /{ }^{144} \mathrm{Nd}$ & $2 \sigma$ & $\varepsilon_{\mathrm{Nd}}$ & ${ }^{87} \mathrm{Sr} /{ }^{86} \mathrm{Sr}$ \\
\hline S19E1 & V1 & 37.7907 & 15.3018 & 17.7224 & & 0.0000073 & & & & & \\
\hline S19E2 & V1 & 37.1751 & 15.2492 & 16.9346 & 0.282636 & 0.0000048 & -4.82 & & & & \\
\hline S38E2 & V1 & 36.9612 & 15.157 & 16.6579 & 0.282607 & 0.0000042 & -5.84 & & & & 0.70780 \\
\hline S38E8 & V1 & 36.7908 & 15.1218 & 16.5386 & 0.282612 & 0.0000042 & -5.65 & 0.512302 & 0.0000063 & -6.56 & 0.70807 \\
\hline S40E1 & V1 & 38.7418 & 15.4345 & 18.6374 & & & & 0.512350 & 0.0000047 & -5.62 & 0.70636 \\
\hline S40E2 & $\mathrm{V} 1$ & 38.7234 & 15.4236 & 18.6007 & & & & 0.511881 & 0.0000088 & -14.76 & 0.70628 \\
\hline S1E1 & V2 & 37.7479 & 15.3743 & 17.9969 & 0.283198 & 0.0000041 & 15.06 & & & & 0.70338 \\
\hline S1E3 & V2 & 37.8174 & 15.4329 & 18.0711 & 0.283198 & 0.0000034 & 15.08 & & & & 0.70338 \\
\hline S1E4 & V2 & 37.7933 & 15.3716 & 18.0389 & 0.283193 & 0.000004 & 14.89 & & & & 0.70332 \\
\hline S3E1 & V2 & 38.5017 & 15.489 & 18.7265 & & & & & & & 0.70362 \\
\hline S4E1 & V2 & 37.714 & 15.4216 & 18.0089 & 0.283203 & 0.0000079 & 15.23 & & & & 0.70311 \\
\hline S5E11 & V2 & 37.4929 & 15.1063 & 16.915 & & 0.0000028 & & 0.512345 & 0.0000047 & -5.71 & \\
\hline S5E5 & V2 & 37.2793 & 15.0701 & 16.9389 & 0.282652 & 0.0000036 & -4.26 & & & & 0.70679 \\
\hline S5E6 & V2 & 37.3562 & 15.0888 & 17.0592 & 0.282692 & 0.000003 & -2.84 & 0.512506 & 0.0000044 & -2.57 & 0.70652 \\
\hline S6E6 & V2 & 37.7648 & 15.4218 & 18.037 & 0.283157 & 0.0000048 & 13.61 & & & & 0.70330 \\
\hline S6E9 & V2 & 38.0612 & 15.4362 & 18.2839 & 0.283138 & 0.0000049 & 12.94 & & & & 0.70628 \\
\hline S7E6 & V2 & 37.9231 & 15.443 & 18.098 & 0.283177 & 0.0000077 & 14.31 & & & & 0.70338 \\
\hline S7E7 & V2 & 37.9827 & 15.4257 & 18.1173 & 0.283173 & 0.0000036 & 14.19 & & & & 0.70349 \\
\hline S7E9 & V2 & 38.0256 & 15.3296 & 17.9856 & 0.283193 & 0.000005 & 14.9 & & & & 0.70363 \\
\hline $\mathrm{S} 15 \mathrm{H} 4$ & V2 & 37.5416 & 15.3724 & 17.9168 & 0.283220 & 0.0000034 & 15.85 & & & & 0.70309 \\
\hline S20E15 & V2 & 37.811 & 15.3603 & 17.9032 & 0.283104 & 0.0000043 & 11.74 & & & & 0.70369 \\
\hline S20E7 & V2 & 38.4594 & 15.3964 & 18.4259 & 0.283059 & 0.0000033 & 10.16 & & & & 0.70398 \\
\hline S27E12 & V2 & 37.7582 & 15.4339 & 18.099 & 0.283202 & 0.0000029 & 15.21 & & & & 0.70794 \\
\hline S27E13 & V2 & 37.6621 & 15.4177 & 18.0158 & 0.283211 & 0.0000044 & 15.52 & & & & 0.70315 \\
\hline S27E18 & V2 & 37.8792 & 15.3751 & 18.0833 & 0.283170 & 0.0000046 & 14.09 & & & & 0.70335 \\
\hline S38E10 & V2 & 38.0322 & 15.3567 & 18.0635 & 0.283115 & 0.0000034 & 12.12 & & & & 0.70374 \\
\hline S39E1 & V2 & 37.1137 & 15.0627 & 16.4893 & 0.282501 & 0.0000046 & -9.58 & 0.512220 & 0.0000042 & -8.15 & 0.70624 \\
\hline S41E3 & V2 & 36.8255 & 14.9913 & 16.1358 & 0.282531 & 0.0000048 & -8.51 & & & & 0.70704 \\
\hline S42E2 & V2 & 36.8122 & 15.0013 & 16.1661 & 0.282565 & 0.0000043 & -7.31 & & & & 0.70665 \\
\hline S42E5 & V2 & 36.8 & 15.0014 & 16.1686 & 0.282574 & 0.0000027 & -7.01 & 0.512303 & 30.000006 & -6.54 & 0.70673 \\
\hline S43E1 & V2 & 37.9194 & 15.3688 & 18.0556 & 0.283116 & 0.0000061 & 12.15 & & & & 0.70355 \\
\hline S43E4 & V2 & 37.8974 & 15.4283 & 18.0467 & 0.283139 & 0.0000104 & 12.97 & 0.512992 & 0.0000052 & 6.9 & 0.70357 \\
\hline S43E6 6 & V2 & 37.7803 & 15.3919 & 17.9208 & 0.283175 & 0.000005 & 14.25 & & & & 0.70337 \\
\hline S44E2 & V2 & 37.7681 & 15.4128 & 18.0671 & 0.283165 & 0.0000053 & 13.89 & & & & 0.70330 \\
\hline S44E7 & V2 & 37.9074 & 15.4131 & 18.0767 & 0.283176 & 0.0000073 & 14.29 & 0.513050 & 0.0000083 & 8.05 & 0.70356 \\
\hline S44E8 & V2 & 37.5621 & 15.3715 & 17.9248 & 0.283204 & 0.0000053 & 15.26 & & & & 0.70328 \\
\hline S45E4 & V2 & 37.9674 & 15.4621 & 18.1573 & 0.283230 & 0.000005 & 16.18 & & & & 0.70326 \\
\hline S45E9 & V2 & 37.8374 & 15.2977 & 17.7873 & 0.283065 & 0.0000109 & 10.35 & 0.512883 & 0.0000061 & 4.78 & 0.70391 \\
\hline S2E2 & V3 & 37.8894 & 15.4361 & 18.2036 & 0.283193 & 0.0000055 & 14.88 & & & & 0.70338 \\
\hline S2E3 & V3 & 38.042 & 15.4536 & 18.3113 & & & & & & & 0.70335 \\
\hline S2E5 & V3 & 37.9368 & 15.4521 & 18.202 & & & & & & & 0.70331 \\
\hline S2E7 & V3 & 38.5979 & 15.4975 & 18.94 & 0.283124 & 0.0000063 & 12.46 & 0.512977 & 0.0000069 & 6.62 & 0.70377 \\
\hline S2E8 & V3 & 38.5267 & 15.4941 & 18.808 & 0.283155 & 0.0000048 & 13.56 & 0.512989 & 0.000006 & 6.84 & 0.70366 \\
\hline S2E9 & V3 & 37.9398 & 15.4554 & 18.2417 & 0.283172 & 0.0000045 & 14.14 & 0.513054 & 0.0000044 & 8.12 & 0.70822 \\
\hline S8E13 & V3 & 37.9907 & 15.4015 & 18.2182 & 0.283174 & 0.0000046 & 14.22 & 0.513033 & 0.000009 & 7.67 & 0.70353 \\
\hline S8E6 & V3 & 39.0141 & 15.5255 & 19.112 & 0.283083 & 0.0000046 & 11 & 0.512719 & 0.0000065 & 1.54 & 0.70392 \\
\hline S9E1 & V3 & 38.1598 & 15.4592 & 18.4869 & 0.283191 & 0.0000051 & 14.82 & & & & \\
\hline S11E10 & V3 & 38.0766 & 15.4443 & 18.4272 & 0.283203 & 0.000004 & 15.23 & & & & 0.70348 \\
\hline $\mathrm{S} 26 \mathrm{H} 1$ & V3 & 38.2176 & 15.5662 & 18.2994 & 0.283198 & 0.0000036 & 15.05 & & & & \\
\hline $\mathrm{S} 26 \mathrm{H} 3$ & V3 & 37.9707 & 15.4411 & 18.3145 & 0.283205 & 0.0000043 & 15.3 & 0.513094 & 0.0000077 & 8.89 & 0.70345 \\
\hline S33E12 & V3 & 38.4105 & 15.4844 & 18.6862 & 0.283192 & 0.0000074 & 14.86 & & & & \\
\hline S33E7 & V3 & 38.7609 & 15.4922 & 19.075 & 0.283111 & 0.0000074 & 11.97 & & & & \\
\hline S35E11 & V3 & & & & 0.283171 & 0.000005 & 14.1 & 0.513027 & 0.0000122 & 7.54 & 0.70354 \\
\hline S35E12 & V3 & 38.0041 & 15.453 & 18.392 & & & & & & & 0.70336 \\
\hline S35E3 & V3 & 37.9532 & 15.4402 & 18.2024 & 0.283188 & 0.0000049 & 14.7 & & & & \\
\hline S35E5 & V3 & 38.0145 & 15.4499 & 18.2868 & 0.283182 & 0.0000048 & 14.49 & 0.513055 & 0.0000098 & 8.13 & 0.70363 \\
\hline S35E8 & V3 & 37.9179 & 15.4556 & 18.2058 & & & & & & & 0.70330 \\
\hline S36E5 & V3 & 37.9807 & 15.4298 & 18.3146 & 0.283186 & 0.0000046 & 14.64 & & & & \\
\hline $\mathrm{S} 21 \mathrm{H} 1$ & V4 & 38.3919 & 15.4636 & 18.6247 & 0.283150 & 0.0000035 & 13.36 & 0.512990 & 0.0000084 & 6.87 & 0.70367 \\
\hline $\mathrm{S} 21 \mathrm{H} 2$ & V4 & 38.0081 & 15.4547 & 18.2627 & 0.283223 & 0.0000039 & 15.95 & & & & \\
\hline S29E2 & V4 & 38.3614 & 15.4604 & 18.4962 & 0.283182 & 0.0000045 & 14.49 & & & & \\
\hline S30E1 & V4 & 38.4071 & 15.4795 & 18.6598 & 0.283145 & 0.0000023 & 13.19 & 0.512992 & 0.0000053 & 6.91 & 0.70806 \\
\hline S30E4 & V4 & 38.4888 & 15.5065 & 18.8252 & 0.283146 & 0.0000025 & 13.23 & 0.512984 & 0.0000061 & 6.76 & 0.70376 \\
\hline $\mathrm{S} 13 \mathrm{H} 5$ & dike & 37.8156 & 15.3998 & 18.1175 & & & & & & & 0.70332 \\
\hline $\mathrm{S} 14 \mathrm{H} 2$ & dike & 38.5245 & 15.5106 & 18.765 & 0.283142 & 0.0000047 & 13.09 & 0.512985 & 0.000009 & 6.73 & 0.70364 \\
\hline $\mathrm{S} 15 \mathrm{H} 3$ & dike & 38.4756 & 15.4871 & 18.7332 & 0.283160 & 0.0000038 & 13.74 & & & & 0.70364 \\
\hline S20E18 & dike & 38.5508 & 15.4971 & 18.7477 & 0.283154 & 0.0000057 & 13.52 & 0.512984 & 0.0000051 & 6.71 & 0.70379 \\
\hline $\mathrm{S} 22 \mathrm{H} 2$ & sill & 37.8774 & 15.4337 & 18.2553 & 0.283213 & 0.0000047 & 15.6 & 0.513095 & 0.0000171 & 8.87 & \\
\hline $\mathrm{S} 22 \mathrm{H} 4$ & dike & 38.5058 & 15.4949 & 18.7357 & 0.283153 & 0.0000048 & 13.48 & 0.512984 & 0.0000051 & 6.71 & 0.70611 \\
\hline $\mathrm{S} 23 \mathrm{H} 4$ & dike V3 & 38.9386 & 15.5336 & 19.2555 & 0.283128 & 0.0000052 & 12.6 & 0.512822 & 0.0000066 & 3.56 & 0.70380 \\
\hline $\mathrm{S} 23 \mathrm{H} 5$ & dike & 38.812 & 15.4818 & 19.1238 & 0.283153 & 0.0000045 & 13.47 & 0.512909 & 0.000007 & 5.24 & 0.70370 \\
\hline $\mathrm{S} 24 \mathrm{H} 1$ & Sill Itsako & 37.8957 & 15.3504 & 18.0561 & 0.283164 & 0.0000037 & 13.85 & & & & \\
\hline S27E4 & dike & 38.4799 & 15.4969 & 18.8261 & 0.283130 & 0.0000043 & 12.65 & 0.512994 & 0.0000071 & 6.91 & 0.70375 \\
\hline
\end{tabular}

